I I

Well Completion Report for

Corrective Action Unit 443

Central Nevada Test Area

Nye County, Nevada

December 2009

Approved for public release; further dissemination unlimited 
Available for sale to the public from:

U.S. Department of Commerce

National Technical Information Service

5301 Shawnee Road

Alexandria, VA 22312

Telephone: 800.553.6847

Fax: 703.605.6900

E-mail: orders@ntis.gov

Online Ordering: http://www.ntis.gov/help/ordermethods.aspx

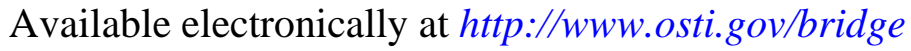

Available for a processing fee to U.S. Department of Energy and its contractors, in paper, from:

U.S. Department of Energy

Office of Scientific and Technical Information

P.O. Box 62

Oak Ridge, TN 37831-0062

Phone: 865.576.8401

Fax: 865.576.5728

Email: reports@adonis.osti.gov

Reference herein to any specific commercial product, process, or service by trade name, trademark, manufacturer, or otherwise, does not necessarily constitute or imply its endorsement, recommendation, or favoring by the United States Government or any agency thereof or its contractors or subcontractors. 


\title{
Well Completion Report for Corrective Action Unit 443 Central Nevada Test Area Nye County, Nevada
}

\author{
December 2009
}


This page intentionally left blank 


\section{Contents}

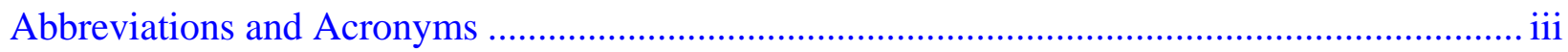

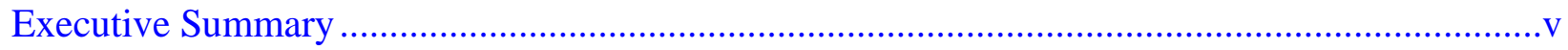

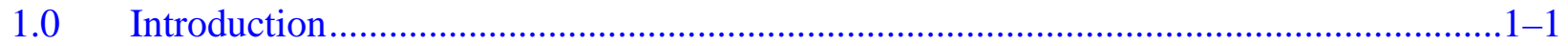

$1.1 \quad$ Site Location and Background...............................................................................1-1

$1.2 \quad$ Scope of Work and Technical Objectives............................................................1-4

$2.0 \quad$ Drilling Program and Methods .......................................................................................

$2.1 \quad$ Environmental Surveys and Checklist ...............................................................2-1

2.2 FMP and Site-Specific Fluid Strategy Letter...................................................2-2

2.3 Source Water for Pad Construction and Drilling Program ...................................2-2

2.4 Construction of Drill Pads and Infiltration Basins.................................................2-3

$2.5 \quad$ Drilling Method ..........................................................................................2-3

2.6 Sampling Methods .......................................................................................2-3

2.6.1 Geologic Material Sampling Methods ....................................................2-4

2.6.2 Radiological Sampling Methods..........................................................2-4

2.6.3 Bromide and Water Quality Sampling Methods.......................................2-4

2.7 Geophysical Well Logging Methods ................................................................2-5

$2.8 \quad$ Well Location Survey …………………………..........................................2-5

3.0 CNTA Geology ………………..............................................................................

3.1 Regional Geologic Setting .....................................................................................

3.2 Local Geologic Setting ………….......................................................................

4.0 Summary of Well MV-4 Activities............................................................................4-1

4.1 Well Drilling and Construction..........................................................................4-1

4.2 Geophysical Well Logging ................................................................................4-2

$4.3 \quad$ Sampling ....................................................................................................4-6

4.3.1 Geologic Material Sampling ...............................................................4-6

4.3.2 Radiological Sampling and Monitoring...................................................4-8

4.3.3 Bromide and Water Quality Sampling....................................................4-8

4.4 Initial Well Development...................................................................................4-8

4.5 Pump Installation and Final Well Development ....................................................4-9

$5.0 \quad$ Summary of Well MV-5 Activities.............................................................................

$5.1 \quad$ Well Drilling and Construction............................................................................5-1

5.2 Geophysical Well Logging ……………………...............................................5-2

5.3 Sampling ..................................................................................................

5.3.1 Geologic Material Sampling ...................................................................5-7

5.3.2 Radiological Sampling and Monitoring..................................................5-8

5.3.3 Bromide and Water Quality Sampling....................................................5-8

$5.4 \quad$ Initial Well Development.........................................................................................5-8

5.5 Pump Installation and Final Well Development ....................................................5-9

6.0 Summary of Well UC-1-P-1SRC Activities ................................................................6-1

6.1 Well Construction ...........................................................................................6-1

6.2 Geophysical Well Logging ...............................................................................6-2

6.3 Sampling ......................................................................................................6-2

6.3.1 Radiological Sampling and Monitoring....................................................6-2

6.3.2 Bromide and Water Quality Sampling.......................................................6-2

6.4 Pump Installation and Well Development ...........................................................6-5 


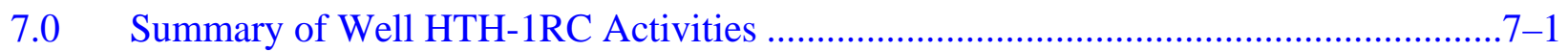

7.1 Well Construction .....................................................................................

7.2 Geophysical Well Logging ………………….................................................

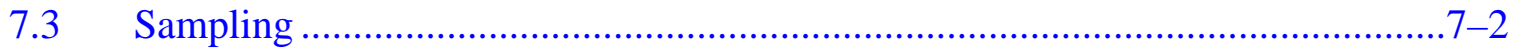

7.3.1 Radiological Sampling and Monitoring...................................................

7.3.2 Bromide and Water Quality Sampling......................................................

7.4 Development and Pump Installation................................................................7-5

8.0 Summary of Miscellaneous Well Site Activities .............................................................8-1

8.1 Removal of Electric Pumps and Installation of Bladder Pumps............................8-1

8.2 Redevelopment of Piezometers..........................................................................8-1

8.2.1 MV-1 Upper Piezometer.......................................................................8-2

8.2.2 MV-3 Upper Piezometer.........................................................................8-2

8.2.3 MV-2 Lower Piezometer ………........................................................8-2

9.0 Environmental Compliance and Waste Management..........................................................9-1

9.1 Waste Management............................................................................................9-1

9.2 Source Water Management................................................................................9-1

$9.3 \quad$ Fluid Management .......................................................................................9-1

10.0 Site Health and Safety.........................................................................................10-1

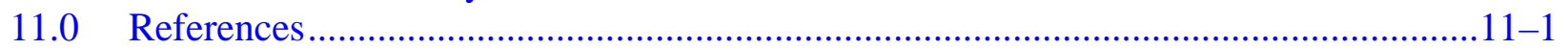

\section{Figures}

Figure 1-1. CNTA Location Map............................................................................... 1-2

Figure 1-2. Location Map of Monitoring Wells and Boundaries at CNTA ................................. 1-3

Figure 3-1. Preexisting Faults in the Quaternary Valley-Fill Deposits........................................ 3-3

Figure 4-1. As-Built Well MV-4 ........................................................................................ 4-3

Figure 4-2. MV-4 Geophysical Logs ....................................................................... 4-5

Figure 4-3. Deviation Plot for Well MV-4 ………............................................................... 4-6

Figure 4-4. MV-4 Bromide versus Gallons Removed ............................................................ 4-10

Figure 5-1. As-Built Well MV-5........................................................................................ 5-3

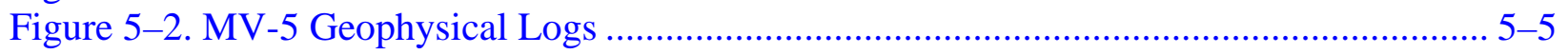

Figure 5-3. Deviation Plot of Well MV-5 ………......................................................... 5-6

Figure 5-4. MV-5 Bromide versus Gallons Removed ............................................................... 5-9

Figure 6-1. As-Built Well UC-1-P-1SRC ……….............................................................. 6-3

Figure 7-1. As-Built Well HTH-1RC...............................................................................

\section{Appendixes}

Appendix A HTH-2 Sample Data and 2009 Well Survey Data

Appendix B MV-4 Data

Appendix C MV-5 Data

Appendix D UC-1-P-1SRC Data

Appendix E HTH-1RC Data

Appendix F Miscellaneous Data

Appendix G Response to Comments 


\section{Abbreviations and Acronyms}

API

AWG

bgs

Boart

CADD

CAP

CAU

cfm

CNTA

DOE

DRI

EPA

EUE

FI

FMP

$\mathrm{ft}$

$\mathrm{ft}^{3}$

gpm

JSA

LM

MCL

MDA

MDC

$\mathrm{mg} / \mathrm{L}$

MV

$\mathrm{NaBr}$

NAIL

NDEP

NTU

OD

$\mathrm{pCi} / \mathrm{L}$
American Petroleum Institute

American Wire Gauge

below ground surface

Boart Longyear Drilling Services

Corrective Action Decision Document

Corrective Action Plan

Corrective Action Unit

cubic feet per minute

Central Nevada Test Area

U.S. Department of Energy

Desert Research Institute

U.S. Environmental Protection Agency

external upset ends

Field Instructions

Fluid Management Plan

feet

cubic feet

gallons per minute

job safety analysis

(DOE) Office of Legacy Management

maximum contaminant level

minimum detectable activity

minimum detectable concentration

milligrams per liter

monitor/validation

sodium bromide

nuclear annulus investigation log

Nevada Division of Environmental Protection

nephelometric turbidity unit

outside diameter

picocuries per liter

Production Multi-Finger Imaging Tool 
PVC polyvinyl chloride

ROW right-of-way

SGZ surface ground zero

Page iv 


\section{Executive Summary}

The drilling program described in this report is part of a new corrective action strategy for Corrective Action Unit (CAU) 443 at the Central Nevada Test Area (CNTA). The drilling program included drilling two boreholes, geophysical well logging, construction of two monitoring/validation (MV) wells with piezometers (MV-4 and MV-5), development of monitor wells and piezometers, recompletion of two existing wells (HTH-1 and UC-1-P-1S), removal of pumps from existing wells (MV-1, MV-2, and MV-3), redevelopment of piezometers associated with existing wells (MV-1, MV-2, and MV-3), and installation of submersible pumps. The new corrective action strategy includes initiating a new 5-year proof-of-concept monitoring period to validate the compliance boundary at CNTA (DOE 2007). The new 5-year proof-of-concept monitoring period begins upon completion of the new monitor wells and collection of samples for laboratory analysis. The new strategy is described in the Corrective Action Decision Document/Corrective Action Plan addendum (DOE 2008a) that the Nevada Division of Environmental Protection approved (NDEP 2008).

The new corrective action strategy and drilling program was designed to enhance the monitoring of the alluvial aquifer. The alluvial aquifer was previously not monitored except for head levels in the upper piezometers of wells MV-1, MV-2, and MV-3 (Figure 1-2). Head levels from different depths at these locations (upper piezometer, lower piezometer, and well at each) indicate that the most likely transport direction from the UC-1 detonation cavity is down, toward densely welded tuff units below the detonation cavity. The existing network was designed to monitor this most likely potential transport pathway. However, given the processes of prompt injection and convective mixing in the nuclear chimney, migration into the alluvial aquifer cannot be ruled out. Alluvial wells are typically more productive than those in the deeper volcanic section, making the alluvial aquifer the most likely source for future groundwater development and therefore the most likely access path to potential receptors.

Interpretations of head levels and seismic data indicated that the downgradient flow direction in the alluvial aquifer is generally to the southeast. Additionally, large differences in head levels at existing wells on either side of the southeast bounding graben fault and offsets of seismic reflectors across the site, suggested that faults at the site act as barriers to flow. The MV-4 and MV-5 wells were designed and positioned to not only monitor for potential contaminant migration in the alluvial aquifer, but to also confirm that the southeast bounding graben fault acts as a flow barrier. The wells were positioned in locations where they would penetrate the downthrown block within the graben and cross the fault into the upthrown block outside the graben (Figure 1-2). The wells were dually completed with a piezometer in the shallow alluvial aquifer within the graben (downthrown block) and a well in the lower alluvial aquifer outside the graben (upthrown block). Initial measurements indicate that alluvial aquifer heads inside the graben are roughly $250 \mathrm{ft}$ higher than those across the fault, outside the graben.

Samples of the drilling fluid, source water, and groundwater discharged during the development of the monitor wells and piezometers were collected as part of the drilling program at CNTA. Sample results indicated that tritium concentrations were below the U.S. Environmental Protection Agency's maximum contaminant level of 20,000 picocuries per liter (pCi/L) and the $10,000 \mathrm{pCi} / \mathrm{L}$ notification level established in the Fluid Management Plan throughout the drilling program. A few sample analyses initially indicated detectable concentrations of tritium, but when 
the samples were reanalyzed with close adherence to the procedure of limiting their exposure to light prior to analysis, the results were within background ranges.

The entire drilling program (mobilizing; drilling, constructing, developing, and installing pumps in the new wells; and recompleting, redeveloping, and removing pumps in existing wells) was accomplished in 58 days (April 16 through June 12, 2009). Operations were conducted 24 hours per day (during two 12-hour shifts) and 7 days per week for the duration of the project; for a few days during mobilization and demobilization of the project, work was only performed during daylight hours. 


\subsection{Introduction}

This Well Completion Report is provided as part of the implementation of the addendum to the Corrective Action Decision Document (CADD)/Corrective Action Plan (CAP) for Corrective Action Unit (CAU) 443 at the Central Nevada Test Area (CNTA) (DOE 2008a). The CADD/CAP is part of an ongoing investigation, funded by the U.S. Department of Energy (DOE) Office of Legacy Management (LM), of CAU 443 at CNTA. Field activities associated with the project were conducted as part of the Federal Facility Agreement and Consent Order (FFACO 1996) and in accordance with applicable Nevada Division of Environmental Protection (NDEP) policies and regulations. Investigation activities included drilling two monitor/validation (MV) wells (MV-4 and MV-5) and recompleting two existing wells (UC-1-P-1S and HTH-1) at CNTA. This report summarizes the field activities and data collected during the investigation.

\subsection{Site Location and Background}

CNTA is north of U.S. Highway 6, approximately 30 miles north of Warm Springs in Nye County, Nevada (Figure 1-1). The U.S. Atomic Energy Commission (predecessor to DOE) acquired CNTA in the early 1960s to develop sites for underground nuclear testing that could serve as alternatives to the Nevada Test Site. Three emplacement boreholes-UC-1, UC-3, and UC-4-were drilled at CNTA for underground nuclear weapons testing. The initial underground nuclear test, Project Faultless, was conducted in borehole UC-1 at a depth of 3,199 feet (ft) below ground surface (bgs) on January 19, 1968. The yield of the Project Faultless test was estimated to be 0.2 to 1 megaton (DRI 1999). The test resulted in a down-dropped fault block (graben) visible at land surface (Figure 1-2). No further nuclear testing was conducted at CNTA, and the site was decommissioned as a testing facility in 1973.

Surface and subsurface contamination resulted from the underground nuclear testing at CNTA. Contamination at the surface was identified as CAU 417. Surface restoration was completed in 1999, and the results are summarized in the Closure Report for Corrective Action Unit 417: Central Nevada Test Area Surface Nevada (DOE 2001). Contamination in the subsurface is believed to be restricted to near the UC-1 detonation cavity and related collapse chimney, and is identified as CAU 443. For several years, groundwater samples have been collected annually from existing monitor wells MV-1, MV-2, MV-3, UC-1-P-1S, HTH-1, and HTH-2, near UC-1. Analyses of these samples have indicated only natural background levels of radionuclides. The corrective action process for the subsurface CAU 443 has not been completed. Site restoration activities associated with the subsurface are summarized in the remainder of this section.

A Corrective Action Investigation Plan (DOE 1999) was developed and approved for CAU 443 in 1999. That plan outlined the corrective action investigation's objectives:

- Determine the characteristics of the groundwater flow system, sources of contamination, and transport processes, to acceptable levels of uncertainty;

- Develop a credible numerical model of groundwater flow and contaminant transport for the UC-1 Subsurface Corrective Action Site and downgradient areas; and

- Develop stochastic predictions of the contaminant boundary, at an acceptable level of uncertainty (DOE 1999). 


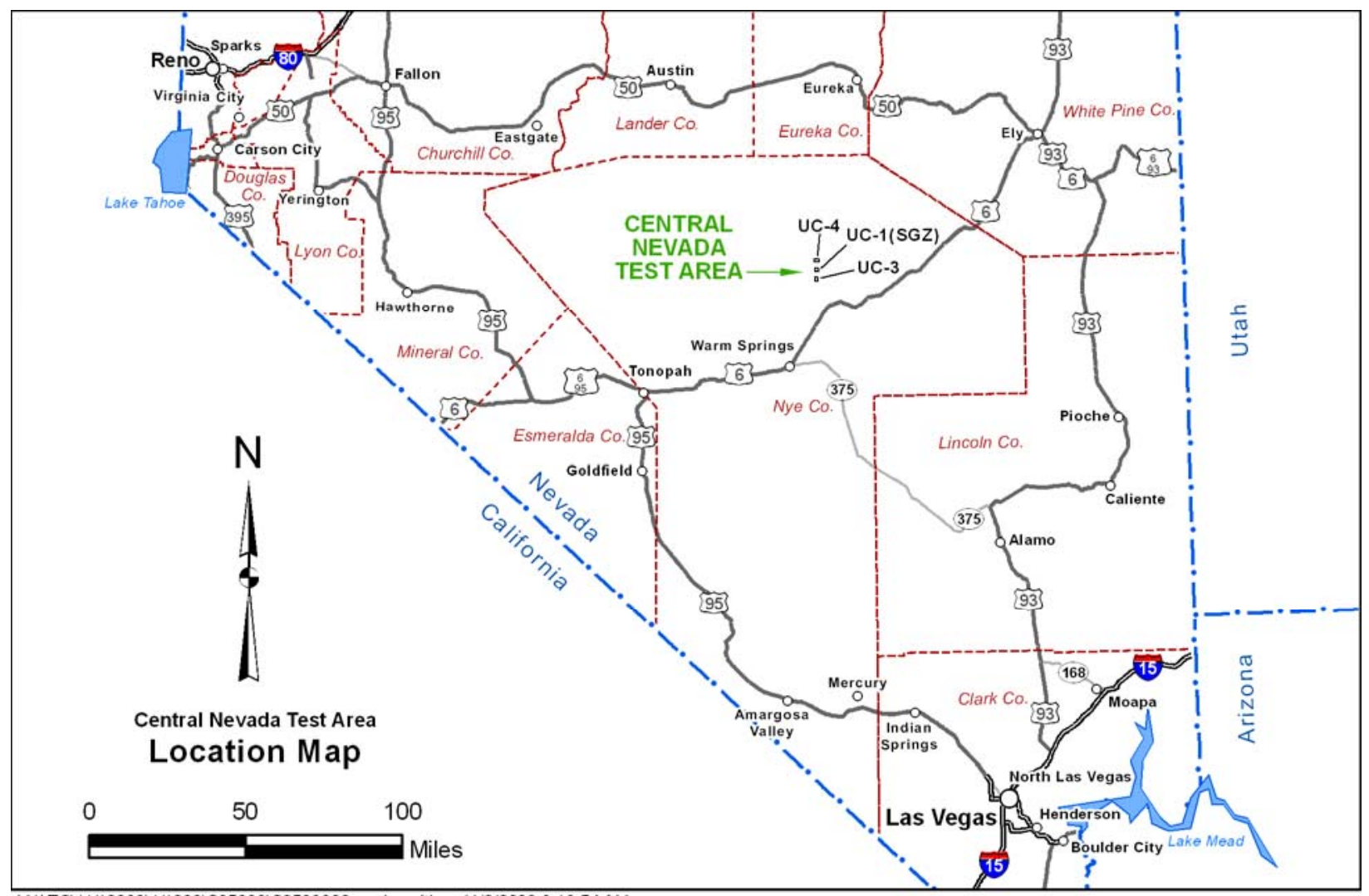

M:ILTS111110083I1110001S05939IS0593900.mxd smithw 11/3/2009 8:18:54 AM

Figure 1-1. CNTA Location Map

These objectives were accomplished using existing data to develop a numeric model and predict the contaminant boundary for the site (DRI 1999).

Results of the corrective action investigation and the corrective action evaluation were presented in the CADD/CAP (DOE 2004). Modeling indicated that groundwater velocities at the site were very slow (due to very low hydraulic conductivities) and predicted that the contaminant boundary would be very small (within two to three radii of the cavity from the working point [DOE 2004]). A compliance boundary was negotiated that factored in modeling results as well as associated uncertainties, especially with respect to the potential effects of the nuclear test within the down-dropped fault block. The compliance boundary corresponds approximately to the surface boundaries of the fault block and is generally contained within the land withdrawal boundary (Figure 1-2). The preferred corrective action alternative selected in the CADD/CAP was proof-of-concept monitoring with institutional controls.

Three wells (MV-1, MV-2, and MV-3) were installed in 2005 for the dual purpose of monitoring radioisotope concentrations and head levels and validating the flow and transport model. Hydraulic heads observed in these wells significantly disagreed with those predicted by the groundwater flow model, which meant that the model could not be validated. Instead of additional modeling, DOE proposed a new corrective action strategy in which the monitoring network would be enhanced by installing two new alluvial monitor wells (MV-4 and MV-5), recompleting the existing well HTH-1 (volcanic sediments), and initiating a new 5-year proof-ofconcept monitoring period to validate the compliance boundary (DOE 2007). The new 


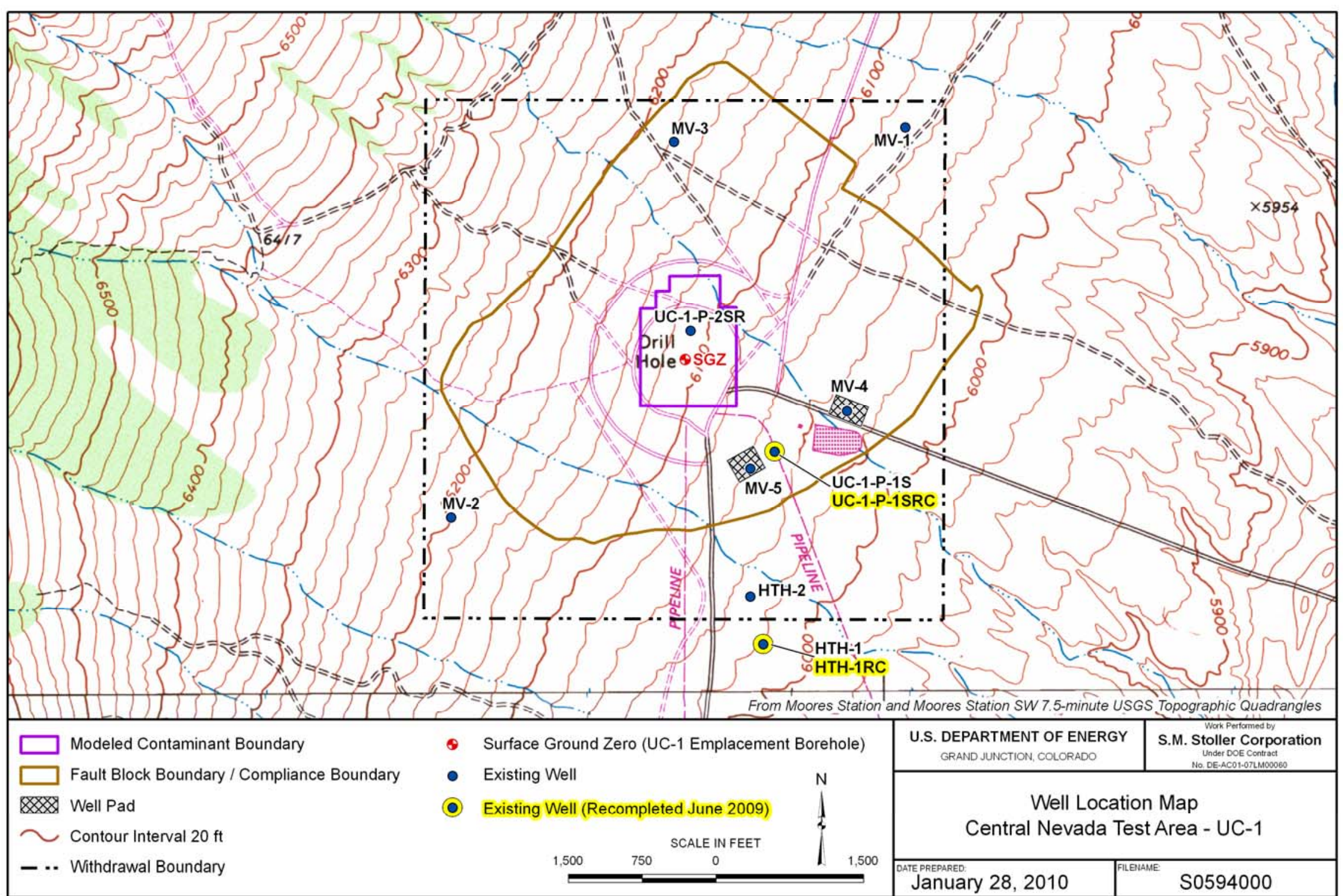

M:LTS|111100831111000|S059401S0594000.mxd smithw 1/28/2010 1:57:55 PM

Figure 1-2. Location Map of Monitoring Wells and Boundaries at CNTA 
5-year proof-of-concept monitoring period begins upon completion of the new monitor wells and collection of samples for laboratory analysis. The CADD/CAP addendum (DOE 2008a) that was approved by NDEP (NDEP 2008) describes the revised approach. Refer to Figure 1-2 for a map showing the new well locations.

\subsection{Scope of Work and Technical Objectives}

The scope of the drilling program at CNTA included:

- $\quad$ Construction of drill pads with infiltration basins;

- $\quad$ Drilling of two boreholes;

- $\quad$ Geophysical well logging;

- $\quad$ Construction of two monitor wells with piezometers (MV-4 and MV-5);

- $\quad$ Development of monitor wells and piezometers (MV-4 and MV-5);

- $\quad$ Recompletion of two existing wells HTH-1 and UC-1-P-1S;

- $\quad$ Removal of pumps from existing wells MV-1, MV-2, and MV-3;

- $\quad$ Redevelopment of piezometers associated with existing wells MV-1, MV-2, and MV-3; and

- Installation of electric submersible pumps in wells MV-4, MV-5, and UC-1-P-1S.

The objective of the CNTA drilling program is to establish new monitoring locations in the alluvial aquifer for obtaining hydrogeologic and groundwater chemistry data and to redevelop selected wells and piezometers at existing monitor locations. To meet these objectives, the drilling program included the following steps:

- Drill and install two monitor wells (MV-4 and MV-5) with piezometers in the alluvium hydraulically downgradient from the UC-1 emplacement borehole. The monitor wells MV-4 and MV-5 are designed as dual completions (well with a piezometer) and have been positioned to monitor the potential southeastward migration of contaminants in the alluvium and also to determine if the southeast-bounding graben fault acts as a barrier to groundwater flow. The wells have been positioned with respect to the fault (northwest-dipping) to allow a piezometer to be placed in the shallow, saturated section of the alluvial aquifer (downthrown block) and a well to be placed in the lower section of the alluvial aquifer (upthrown block; outside the graben).

- $\quad$ Recomplete the existing well UC-1-P-1S for use as a monitor well in the upper portion of the alluvial aquifer. This required removing the existing well casing, setting a cement seal at the total depth of the borehole, installing a new well casing with filter pack materials, and installing a dedicated submersible electric pump.

- Recomplete existing well HTH-1 with a new well in the upper volcanic section (below the alluvium) and two piezometers, one screened in the lower and one screened in the upper part of the alluvial aquifer. This will provide a sample location in the volcanic section south of the detonation and heads at different depths to allow the vertical gradient to be determined at this location.

- $\quad$ Redevelop the piezometers associated with existing wells MV-1, MV-2, and MV-3 in an effort to increase confidence that head data are representative of the screened interval and not influenced by inadequate development. This will require airlifting or bailing to remove 
sediment and remnant drilling mud from the screened interval of piezometers and restoring the natural hydraulic properties of the formation.

- $\quad$ Remove electric pumps from existing wells MV-1, MV-2, and MV-3. The screened intervals in these wells produce minimal water; therefore, to get a representative sample, the water column in the well must be pulled down to just above the pump during the purge process. Pulling down the water level in this way stresses the pump motors and increases the likelihood that the pumps will fail; if a pump failed, it would need to be replaced before sampling could continue. The pump in MV-1 has failed twice and is not currently operational. Installing bladder pumps and using low-flow sampling techniques will allow representative samples to be obtained from these low-producing wells and avoid the delays and costs associated with pump failures. 
This page intentionally left blank

Page 1-6 


\subsection{Drilling Program and Methods}

The drilling program at CNTA is designed to enhance the current monitoring network by adding new locations in the alluvial aquifer downgradient of the detonation. The alluvial aquifer was previously not monitored except for head levels in the upper piezometers of wells MV-1, MV-2, and MV-3 (Figure 1-2). Head levels at these locations (two piezometers and a well at each) indicate that the most likely transport direction from the UC-1 detonation zone is down, toward densely welded tuff units below the detonation cavity. The current network is designed to monitor this potential transport pathway. However, given the processes of prompt injection and convective mixing in the nuclear chimney, migration into the alluvial aquifer cannot be ruled out. Alluvial wells are typically more productive than those in the deeper volcanic section, making the alluvial aquifer the most likely source for future groundwater development and, therefore, the most likely access path to potential receptors.

Execution of the drilling program at CNTA required performing surveys, completing an Environmental Checklist, obtaining the necessary permits and waivers, developing a Fluid Management Plan (FMP) with site-specific fluid strategy letter, establishing a source of water for construction of drill pads and drilling program, construction of drill pads with infiltration basins, and establishing the methods to complete the drilling program. The following sections summarize the activities leading up to the drilling program as well as the methods used during the drilling program.

\subsection{Environmental Surveys and Checklist}

The Desert Research Institute conducted a survey for cultural resources on areas that would potentially be disturbed during the construction of the drill pads and drilling program at CNTA. The results of the survey were summarized in the Cultural Resources Inventory Report SR 120307-1 and provided to the State of Nevada Department of Cultural Affairs, State Historic Preservation Office for review and consideration in February 2008. It was determined that no resources eligible for nomination to the National Register of Historic Properties were found on the surveyed areas, and the State Historic Preservation Office issued a letter dated April 24, 2009, stating that it concurred with this determination.

As required by the National Environmental Policy Act, an Environmental Checklist (LM\#11-08) was prepared to evaluate potential impacts related to the construction of the drill pads, clearing of an area around existing well HTH-1, and clearing a staging area. No significant impacts were identified associated with the planned actions. DOE approved the Environmental Checklist on August 5, 2008. A separate Environmental Checklist (LM\#03-09) was prepared in 2009 that considered the potential impacts related to the drilling program and additional planned activities. No impacts were identified associated with these actions, and DOE approved the Environmental Checklist on April 15, 2009. As part of the Environmental Checklist, DOE contacted the U.S. Department of the Interior's Bureau of Land Management, Tonopah Field Office for information related to listed species present at CNTA. The site is outside of the range for the federally listed desert tortoise, and no other species of concern were known to be present in the area. The area has been highly disturbed by prior activities. 


\subsection{FMP and Site-Specific Fluid Strategy Letter}

Activities associated with the construction of the drill pads and drilling program were initiated with the preparation of the FMP for CNTA (DOE 2009a). The FMP is intended to guide the management of fluids and associated materials generated during subsurface investigation activities and provide the standards that govern their final disposition. Although NDEP is not a signatory to the FMP, it is involved in the negotiation of the content and approves the conditions described within the plan. The initial draft of the FMP was submitted to NDEP in March 2008. NDEP's main comment on the draft was that discharge of pollutants that could be carried into waters of the state is prohibited without a permit. LM responded that all future drilling at CNTA is expected to take place under a far-field strategy and that it is highly unlikely that contaminants will be encountered (DOE 2008b). LM, therefore, proposed to remove the discussion of the nearfield scenario from the revised FMP and add justification for the use of a far-field strategy. NDEP agreed with this approach, and the FMP was approved on February 6, 2009.

In accordance with the FMP, a well-site operation strategy letter was prepared to provide the rationale for selecting the far-field-fluid management strategy and address specific details regarding the nature and configuration of the fluid containment to be used at each well site (DOE 2009b). The Well-Site Fluid Management Strategy letter (DOE 2009b) provided qualitative and quantitative data that supported the far-field strategy and established the use of infiltration basins for managing fluids and materials generated during the drilling and other well site activities. NDEP approved the Well-Site Fluid Management Strategy on April 29, 2009.

\subsection{Source Water for Pad Construction and Drilling Program}

As part of the construction of the drill pads and in preparation for the drilling program at CNTA, a waiver was completed to obtain water from well HTH-2 at the site. The State of Nevada's Department of Conservation and Natural Resources, Division of Water Resources issued the waiver (number M/O-1515) to LM on August 14, 2008, and reissued it on September 25, 2008. The waiver granted permission to drill two new wells (MV-4 and MV-5), recomplete the existing well (HTH-1), and obtain water from well HTH-2 to construct the drill pads. The waiver was amended on two separate occasions, and the final amended wavier (number M/O-1515A) was issued on April 9, 2009, to include the recompletion of existing well UC-1-P-1S and increase the water allotment from well $\mathrm{HTH}-2$ for the drilling program.

Well HTH-2 was selected as a source of water for the construction of drill pads and drilling program at CNTA. This well was selected because it is screened through the upper portion of the alluvial aquifer, it is equipped with an electric submersible pump, and it was used during the drilling program in 2005. Well HTH-2 was also sampled routinely as part of the annual monitoring of the site. Samples collected in March 2008 were analyzed for gamma-emitting radionuclides by high-resolution gamma spectroscopy and tritium using the conventional and enriched methods. The analytical results indicated no detections above the laboratory method detection limits. Refer to Table A-1 in Appendix A for analytical results of samples collected from well HTH-2 in March 2008. 


\subsection{Construction of Drill Pads and Infiltration Basins}

A right-of-way (ROW) application was completed to construct two drill pads with infiltration basins, clear an area around well HTH-1, and establish access to the existing wells at CNTA. The Bureau of Land Management approved the ROW (number N-85175) on August 15, 2008.The construction of the drill pads and staging area for the drilling program was completed in September 2008. The ROW application was later amended to allow the drill pads to be enlarged slightly to accommodate a larger drill rig and provide a cleared area around the existing well UC-1-P-1S. The Bureau of Land Management approved the amended ROW (number N-85175) on May 11, 2009.

As part of the drilling program that began in April 2009, the pads were enlarged, and an area was cleared around well UC-1-P-1S. The MV-4 and MV-5 drill pads were constructed; the final dimensions of well MV-4's drill pad were approximately $250 \mathrm{ft}$ by $185 \mathrm{ft}$, and the final dimensions of well MV-5's drill pad were approximately 280 by $250 \mathrm{ft}$. Each pad included two infiltration basins measuring approximately $80 \mathrm{ft}$ by $70 \mathrm{ft}$, and approximately $15 \mathrm{ft}$ deep. The infiltration basins were designed to contain five times the estimated volume of material to be displaced from the borehole. The MV-4 and MV-5 well pads were situated approximately 1,650 ft east-southeast and 1,200 ft south-southeast of surface ground zero (SGZ), respectively. The surface was cleared around the existing wells UC-1-P-1S and HTH-1 to make a safe working area for equipment and personnel.

\subsection{Drilling Method}

Boart Longyear Drilling Services (Boart) was contracted to perform the drilling program at CNTA. Boart is a licensed drilling contractor (license number 0021976) with the State of Nevada. Boart completed the required notices of intent to drill (application numbers 63065, 63066, 63067, and 63076 for wells MV-4, MV-5, UC-1-P-1S, and HTH-1, respectively). Boart drilled wells MV-4 and MV-5 using an LM 300E top head rotary drill rig. The boreholes were advanced by conventional rotary and dual-tube reverse circulation drilling methods, using waterand polymer-based drilling fluids and a tricone button bit. The drilling method was selected based on expected drilling conditions and past drilling programs at CNTA. Borehole deviation surveys were performed approximately every $300 \mathrm{ft}$ as the borehole was advanced; a geolograph recorded drilling parameters and penetration rates during the drilling. The daily drilling reports included penetration rates, the results of borehole deviation surveys, and other pertinent information.

Fifty-eight days (April 16 through June 12, 2009) were spent mobilizing and drilling; constructing, developing, and installing pumps in the new wells; and recompleting, redeveloping, and removing pumps from existing wells. Operations were conducted 24 hours per day (during two 12-hour shifts) and 7 days per week for the duration of the project; for a few days during mobilization and demobilization of the project, work was only performed during daylight hours.

\subsection{Sampling Methods}

Geologic material, drilling fluid, and groundwater samples were collected during the advancement of the borehole, construction of the wells and piezometers, and development of the wells and piezometers as part of the drilling program at CNTA. Samples included rock cuttings 
for lithologic description, and drilling fluid and groundwater for radiological monitoring and water quality analysis. Samples were collected in accordance with the FMP (DOE 2009a) and Field Instructions (FI) (DOE 2009c). The following sections describe the sampling methods.

\subsubsection{Geologic Material Sampling Methods}

Samples of the drill cuttings were collected during the advancement of the borehole. These samples were collected from the drill rig shaker screen, washed, and composited for $10-\mathrm{ft}$ intervals. A portion of the washed cuttings were placed in a chip tray for lithologic description. Samples of the cuttings were collected to determine the lithologic characteristics of the geologic units penetrated and to provide a detailed lithologic log as drilling progressed. The lithologic descriptions included grain size, mineralogy, alteration, color, fracturing, and other notable geologic characteristics. U.S. Geological Survey terminology and the Munsell Soil Color Chart were used to document the geologic characteristics. The samples obtained during the drilling program are maintained by LM.

\subsubsection{Radiological Sampling Methods}

Samples of the drilling fluid, source water, and groundwater discharged during development were collected and analyzed for tritium on site. A Triathler liquid scintillation counter was used to analyze the samples to ensure that fluid management controls were being implemented in accordance with the FMP and site-specific fluid strategy letter. Samples obtained during the drilling operations were collected at approximately 30-ft intervals or every hour from below the cyclone as fluid entered the mud tank. Samples obtained during the development were collected from the discharge line approximately every 2 hours. All of these samples were collected and analyzed —and the results of sample analyses were documented-in accordance with the Radiological Control Manual (LMS/POL/S04322).

Samples were collected from well HTH-2 and analyzed before each shift began (twice a day) to establish background concentrations for tritium. It was necessary to determine background levels of radiation in groundwater because many geologic strata contain naturally occurring radiation. The background concentrations were recorded and used for all counts during the respective shift. The background samples were collected and analyzed-and the results of sample analyses were documented-in accordance with the Radiological Control Manual.

\subsubsection{Bromide and Water Quality Sampling Methods}

Samples of the drilling fluid, source water, and groundwater discharged during development were collected and analyzed to monitor $\mathrm{pH}$, temperature, specific conductance, bromide, and turbidity. Concentrations of bromide were obtained from the sodium bromide $(\mathrm{NaBr})$ tracer that was added to the makeup/source water used during the drilling, well construction, and development operations. The $\mathrm{NaBr}$ tracer was added to each tanker truck of water obtained from the source well HTH-2. Bromide concentrations in the makeup/source water were generally maintained between 20 and 40 milligrams per liter $(\mathrm{mg} / \mathrm{L})$. The purpose of the tracer was to assist in detecting perched water zones, assist in detecting the groundwater table, and provide a monitoring parameter to establish the effectiveness of well development.

Samples obtained during the drilling operations were collected at approximately 30-ft intervals or every hour from below the cyclone as the fluid entered the mud tank. Samples obtained during 
the development were collected from the discharge line approximately every 2 hours. All of these samples were analyzed on site using a YSI-63 water quality meter, an Orion 9635BNWP ion-selective electrode, and a turbidity meter.

\subsection{Geophysical Well Logging Methods}

Boart contracted COLOG to perform geophysical well logging as part of the drilling program at CNTA. COLOG maintains a radioactive materials license with the State of Colorado (license number Colo. 971-02). COLOG completed the required U.S. Nuclear Regulatory Commission (NRC) Form 241 and obtained an NRC-assigned number (247) for the project. COLOG also obtained authorization - from the State of Nevada's Bureau of Health Care Quality and Compliance, a division of the State's Department of Health and Human Services - to bring the sources required for the logging suite to the site. SUNTRAC Services, Inc., performed a leak test inventory to verify that tools and required sources were not leaking and approved them for use. Copies of the forms, license, and leak test results are maintained in LM records.

The geophysical well logging was performed in accordance with the NRC license, which required that (among other things) the work area be posted and monitored, the work-area postings be removed once work was complete, and instruments be operated according to the manufacturers' instructions. Radiological control personnel performed radiological monitoring during the logging activities. COLOG provided evidence of calibrations (pre-job/post-job) in accordance with American Petroleum Institute (API) guidance, manufacturer specifications, industry standards, and bench calibrations. The data obtained during the logging were set to a ground surface datum and not the drill rig floor. The wire-line logging truck was equipped with calibrated weight indicators and depth-control devices as required.

\subsection{Well Location Survey}

Summit Engineering, a Nevada-registered land surveyor, was contracted to survey new and existing well locations upon completion of the drilling program. The well locations were surveyed June 23 through 26, 2009. The survey provided northings and eastings with top-ofcasing elevations for the existing and new wells, concrete pad, water-access-tube casing, and piezometer casings. All survey data were documented in the Universal Transverse Mercator Zone 11 coordinate system, with horizontal data based on the North American Datum 1927 and vertical data based on the North American Vertical Datum 1929. Refer to Figure 1-2 for a map showing the well locations. The survey data are provided in Table A-2 in Appendix A. 
This page intentionally left blank 


\subsection{CNTA Geology}

Information on the regional and local geologic setting for CNTA was obtained from various sources such as site inspections, well geophysical data, seismic data, U.S. Geological Survey literature, and previous investigation reports. The following sections summarize the regional and local geologic settings.

\subsection{Regional Geologic Setting}

CNTA is in the northern portion of the Hot Creek Valley between the Hot Creek Range to the west and the Squaw Hills and Halligan Mesa to the east. Hot Creek Valley is an elongate graben filled with as much as 4,200 ft of Quaternary and Tertiary alluvium derived from the surrounding mountains. These valley-filling alluvial deposits overlie Tertiary volcanic formations that are laterally equivalent to the formations cropping out in the nearby Squaw Hills and Hot Creek Range (Snyder 1967). The Tertiary volcanic rocks in the Hot Creek Range and Squaw Hills were deposited on Paleozoic sedimentary rocks, which crop out farther to the south and north in the Hot Creek Range, and farther to the north in the Squaw Hills. However, in the hills and mountains adjacent to CNTA, volcanic rocks overwhelmingly dominate the exposed bedrock geology. Surface and subsurface geologic data indicate that CNTA is within the Hot Creek Valley caldera complex, which contains several overlapping volcanic cauldrons. This caldera complex has been disrupted by basin-and-range style normal faulting that formed the Hot Creek Valley graben. Normal faulting in the region still occurs, as evidenced by fault scarps on the surfaces of modern alluvial fans, as well as by the earthquake faults associated with the Faultless test of January 1968.

\subsection{Local Geologic Setting}

Detailed lithologic descriptions for boreholes UC-1, UC1-I-1, and UC1-I-2 at CNTA show the valley-fill alluvial deposits to be poorly sorted volcanic rock fragments and sparse Paleozoic carbonate, chert, and siltstone rock fragments enclosed within a matrix of sand-sized crystals and clay. These rock fragments are rounded to subrounded and range in size from gravel to boulders, although the average size is about 6 inches in diameter. Lithologic descriptions for boreholes HTH-1 and HTH-2 at CNTA indicate that the valley-fill alluvial deposits are similar to those in UC-1, but with a higher percentage of Paleozoic sedimentary rock fragments. In all five of these boreholes, the upper 1,000 ft is largely unconsolidated, and the degree of induration increases downward below this depth. The contact between the alluvium and the underlying volcaniclastic and tuffaceous sediments occurs at depths of approximately 2,400 ft bgs and is based variously on the first appearance of nonwelded tuff or the first appearance of conglomeratic tuffaceous sandstone interbedded with nonwelded tuff (Hoover 1968a). The alluvium encountered in MV-1, MV-2, and MV-3 at CNTA is similarly described as poorly sorted, angular to subrounded, silt, sand, gravel, and cobbles composed primarily of light to dark gray rhyolite, reddish brown rhyolite, and minor amounts of dark gray to black limestone and dolomite, and tan and dark gray siltstone. Concentrations of lithic clasts vary, with silty and clay-rich layers interbedded with sandy layers and layers of gravel, cobbles, and boulders. These three holes encountered the contact with the underlying Tertiary volcaniclastic and tuffaceous sediments at depths of 2,352, 1,960, and 2,410 ft bgs, respectively. This contact in each of these three boreholes was chosen based on the appearance of a grayish yellow, argillically altered, nonwelded tuff with 18 to 25 percent phenocrysts (DOE 2006). 
The Faultless test triggered numerous small earthquakes and aftershocks that resulted in surface subsidence and surface rupture along preexisting faults, caused strike-slip movement along previously unknown subsurface faults, and induced seismic activity as far away as 24 miles (McKeown and Dickey 1969). The Faultless test created a subsidence graben elongated to the northeast and parallel to numerous preexisting faults in the Quaternary valley-fill deposits (Figure 3-1). The graben is bounded by curved faults on the southeast, south, southwest, and northwest, with an apparent hinge line at the northeastern end of the graben (Ekren et al. 1973). Maximum subsidence at the time of the test was $14.8 \mathrm{ft}$. Some of the bounding faults are calculated to dip 77 degrees to the north, based on fault intercepts in post-shot boreholes and post-shot map data. High-speed photography revealed that subsidence occurred immediately following the test, indicating that subsidence resulted from the immediate release of tectonic stress that was triggered by the underground test, and not from the collapse of the test cavity (McKeown et al. 1968; McKeown and Dickey 1969). Collapse chimneys typically extend 4 to 6 cavity radii above the working point, whereas the Faultless test occurred at a depth estimated to be about 10 cavity radii below the surface (Glasstone and Dolan 1977). Analysis of post-shot seismic data indicates that minor strike-slip movement occurred along a buried north-striking fault in Moores Station Wash from 2 to 4 miles south of the Faultless test (Ekren et al. 1973; McKeown and Dickey 1969).

Approximately 7.8 miles of seismic reflection data (total of five individual lines) were acquired at CNTA during the fall of 2007. These seismic profiles were acquired along site roads that radiate from the centrally located UC-1 emplacement well and crossed all of the major faults associated with the graben as well as numerous Holocene faults exposed on the surface. The seismic data indicate that the faults comprising the graben dip from about 72 degrees to 77 degrees toward the interior of the graben. These profiles also reveal the existence of a buried and previously unknown down-to-the-east normal fault to the west of the graben and another similar fault just to the southeast of the graben. Seismic reflections interpreted as the water table are offset across many of these faults, suggesting that some faults act as barriers to groundwater flow in the upper part of the alluvial aquifer and probably deeper. Additionally, the loss of coherence in most seismic reflectors immediately above the Faultless test cavity suggests that these strata have been intensely fractured and the bedding disrupted. 


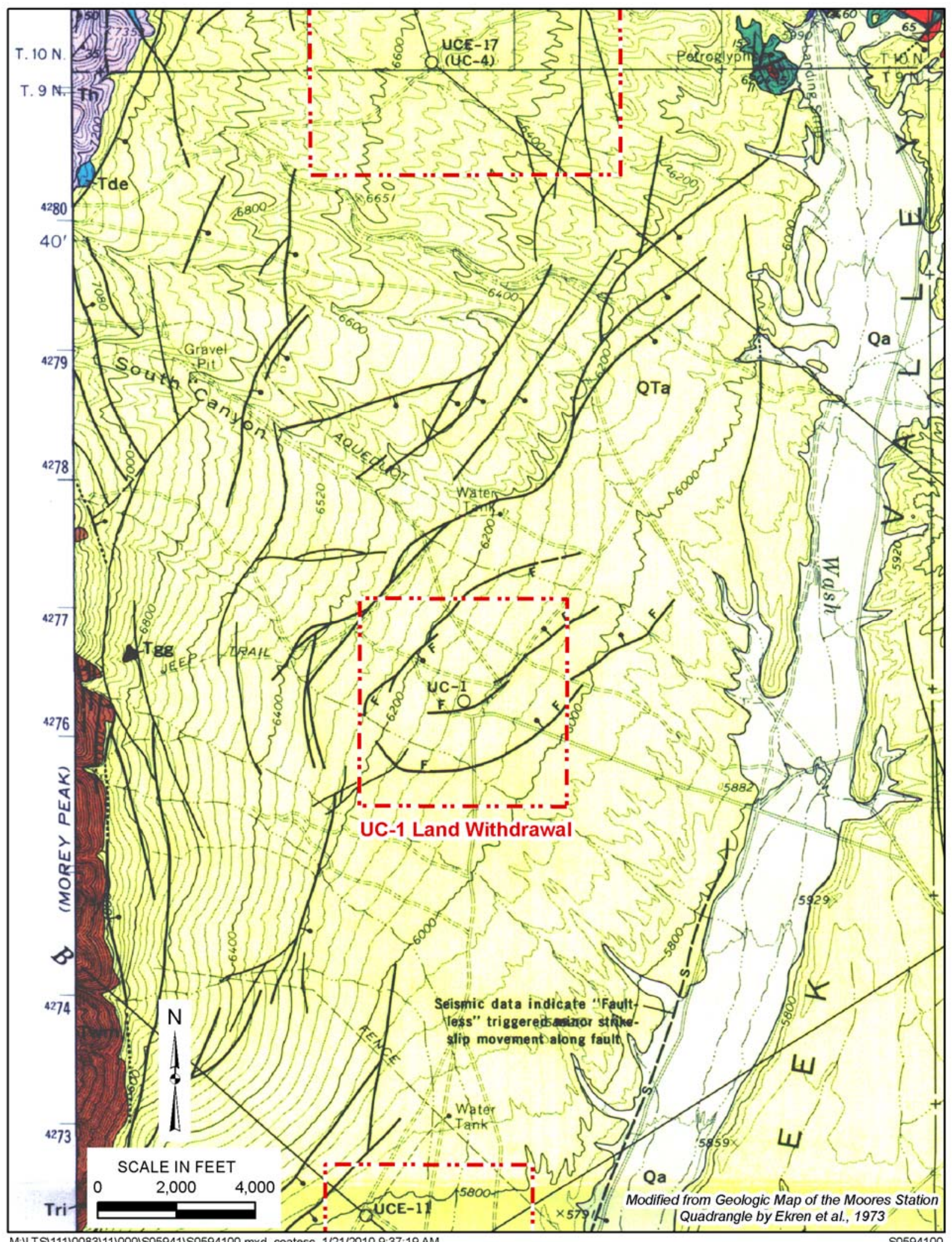

Figure 3-1. Preexisting Faults in the Quaternary Valley-Fill Deposits 
This page intentionally left blank 


\subsection{Summary of Well MV-4 Activities}

Well MV-4 was the first of two new wells constructed at CNTA. This well was drilled and completed approximately 1,650 ft east-southeast of SGZ (Figure 1-2). The drilling of the initial borehole began on April 22, 2009. The borehole was completed to a total depth of 2,223 ft bgs on April 29, 2009. Geophysical logging of the borehole was conducted in two phases. The first phase was conducted from $100 \mathrm{ft}$ bgs to the drilled depth of 2,223 ft bgs and began on April 29, 2009. The second phase was conducted during the installation of the well and piezometer filter pack materials, and began on May 2, 2009. Construction of the piezometer and well was completed on May 5, 2009, to depths of 998.40 and 2,064.18 ft bgs, respectively. Initial airlift development of the well and piezometer was completed on May 9, 2009. The installation of the dedicated pump and final well development took place from May 25 through June 1, 2009. The following sections summarize the well construction, geophysical well logging, sampling, well development, and pump installation activities. Refer to Table B-1 in Appendix B for a chronology of the drilling operations at well MV-4.

\subsection{Well Drilling and Construction}

The installation of well MV-4 included drilling an initial 31-inch-diameter borehole to a depth of $100 \mathrm{ft}$ bgs to allow a 24-inch-diameter carbon-steel casing with fully welded joints to be installed as a surface seal and wellhead control apparatus. This casing was set to a depth of $100 \mathrm{ft}$ bgs and cemented in place using approximately 210 cubic $\left.\mathrm{ft}_{(\mathrm{ft}}{ }^{3}\right)$ of Portland Type II cement. The final borehole was drilled from $100 \mathrm{ft}$ to the completion depth of 2,223 ft bgs using a 12.25-inch tricone button bit. The borehole was plugged back from 2,223 to 2,098 ft bgs with cement upon completion of the geophysical well logging. The selection of well and piezometer screen intervals was based on geologic data collected while drilling (cuttings, drill rates) and the geophysical logs.

Well MV-4 was completed with a well and piezometer in the 12.25-inch borehole. The well consisted of a 5.5-inch-outside diameter (OD) internally ceramic-coated carbon-steel casing. The well was screened from 1,719.33 to 2,023.43 ft bgs with manufactured 3-by-0.078-inch slotted openings on 6-inch centers staggered at 10 degrees with 18 slots per row. The well was completed to a total depth of 2,064.18 ft bgs, which included approximately $40 \mathrm{ft}$ of blank casing below the well screen for a sump. Eight centralizers were placed around the well screen at approximately 40-ft intervals to ensure proper spacing of filter pack materials. The piezometer was constructed with 2.375-inch-OD carbon-steel casing with $60 \mathrm{ft}$ of slotted (0.078-inch) screen installed from 918.25 to $978.25 \mathrm{ft}$ bgs. The piezometer was completed to a total depth of $998.40 \mathrm{ft}$ bgs and included approximately $20 \mathrm{ft}$ of blank casing below the screen for a sump. Two centralizers spaced approximately $40 \mathrm{ft}$ apart were placed around the well casing at the depth of the piezometer screened interval to ensure proper spacing of filter pack materials.

A graded filter pack was installed around the slotted intervals of the well and piezometer. Filter pack materials for MV-4 included 1/8- to 1/4-inch clean gravel and No. 6 clean silica sand. The silica sand was placed above the gravel as transition sand. Gravel and sand filter pack materials were pumped through an NQ tremie pipe using a sand pump. Portland Type II cement was used to seal the formation. A cement seal approximately $608 \mathrm{ft}$ thick, with a 2 percent calcium chloride additive to reduce the cure time, was placed between the well filter pack and the piezometer filter pack to ensure the separation of water-producing zones. Cement was pumped 
down the NQ tremie, followed by a clean-water rinse. The NQ tremie was raised in stages during the placement of the stemming materials to help ensure proper placement without plugging or bridging. COLOG monitored the placement of stemming materials in real time, using a nuclear annulus investigation log (NAIL) to ensure that the placement was correct. Table B-2 in Appendix B lists the well construction materials and volumes used to complete MV-4. Refer to Figure 4-1 for a diagram showing the well construction details of MV-4.

\subsection{Geophysical Well Logging}

COLOG acquired borehole geophysical logs from the MV-4 borehole in two phases. The first phase of geophysical logging was performed in the 12.25-inch-diameter borehole from below the surface casing $(100 \mathrm{ft})$ to the completion depth of approximately 2,223 ft bgs. This phase of the logging suite included caliper, neutron (epithermal and compensated), natural gamma ray, spontaneous potential, deviation, formation density, resistivity (dual laterolog/dual induction), temperature, sonic velocity, and heat pulse flow meter logs. The first phase of logging was completed on May 1, 2009. Refer to Figure 4-2 for a condensed version of the geophysical logs obtained from well MV-4.

The second phase of the logging was performed in the well and included a NAIL. This phase of the logging was completed on May 4, 2009. The NAIL was used for the real-time tagging of stemming materials during well construction. A borehole deviation survey performed within the borehole provided the extent the well deviated from vertical. The deviation survey indicated that the bottom of the borehole had deviated less than 1 degree from vertical, placing the bottom of the borehole and bottom of the well approximately $26.63 \mathrm{ft}$ and $23.35 \mathrm{ft}$ south-southeast from the surface collar, respectively. Refer to Figure 4-3 for a deviation plot of the MV-4 borehole. 


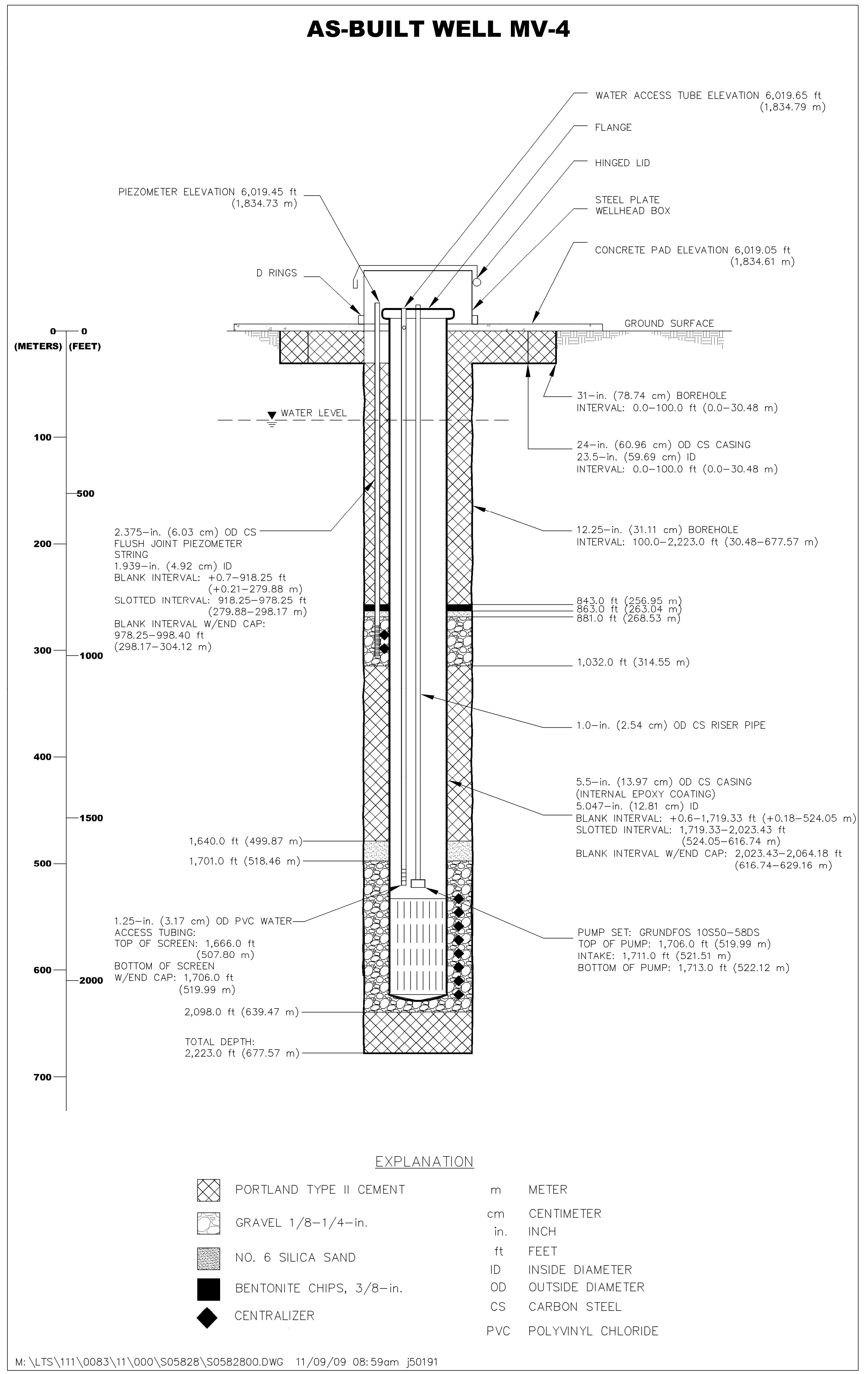

Figure 4-1. As-Built Well MV-4 
This page intentionally left blank 


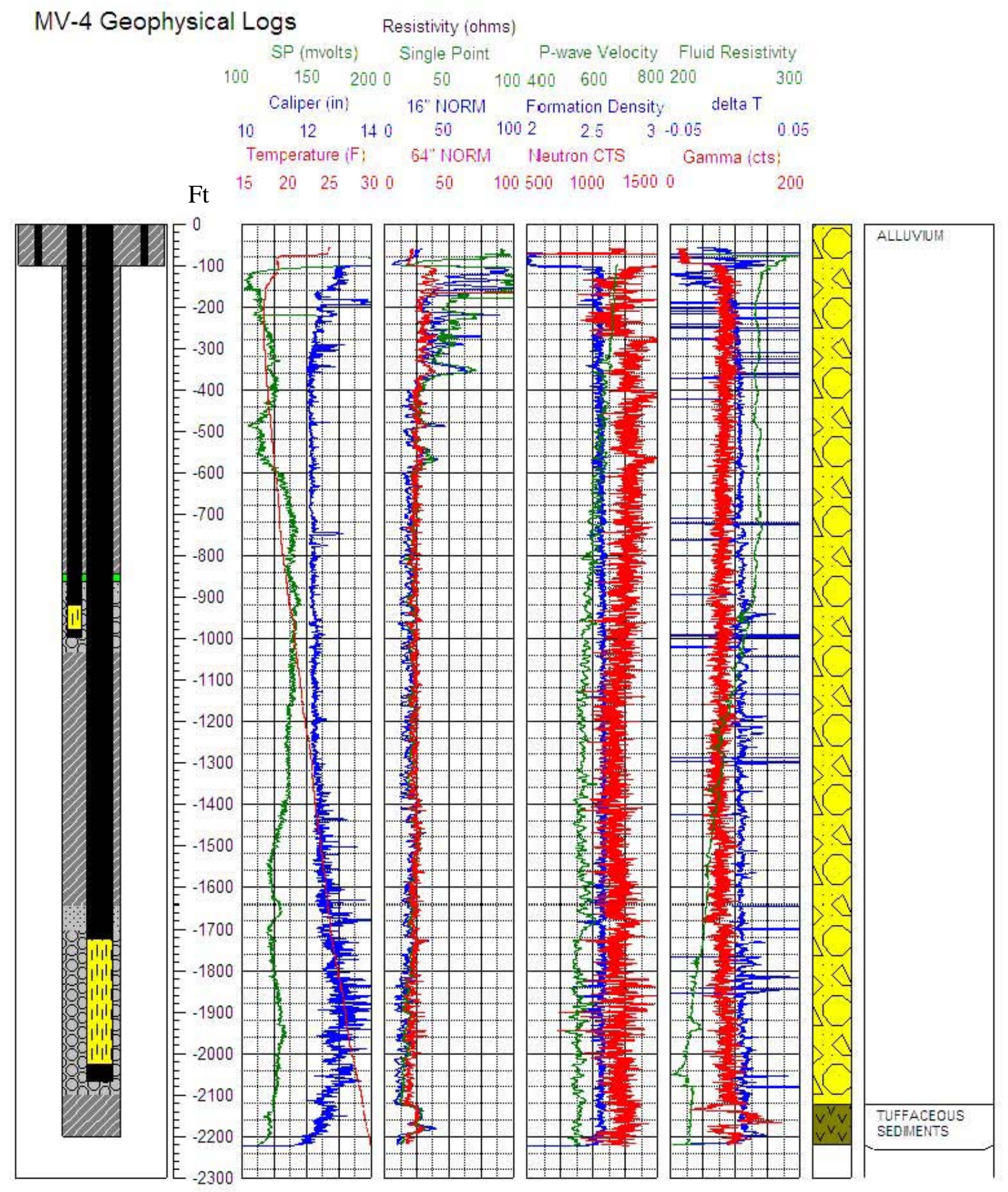

Figure 4-2. MV-4 Geophysical Logs 


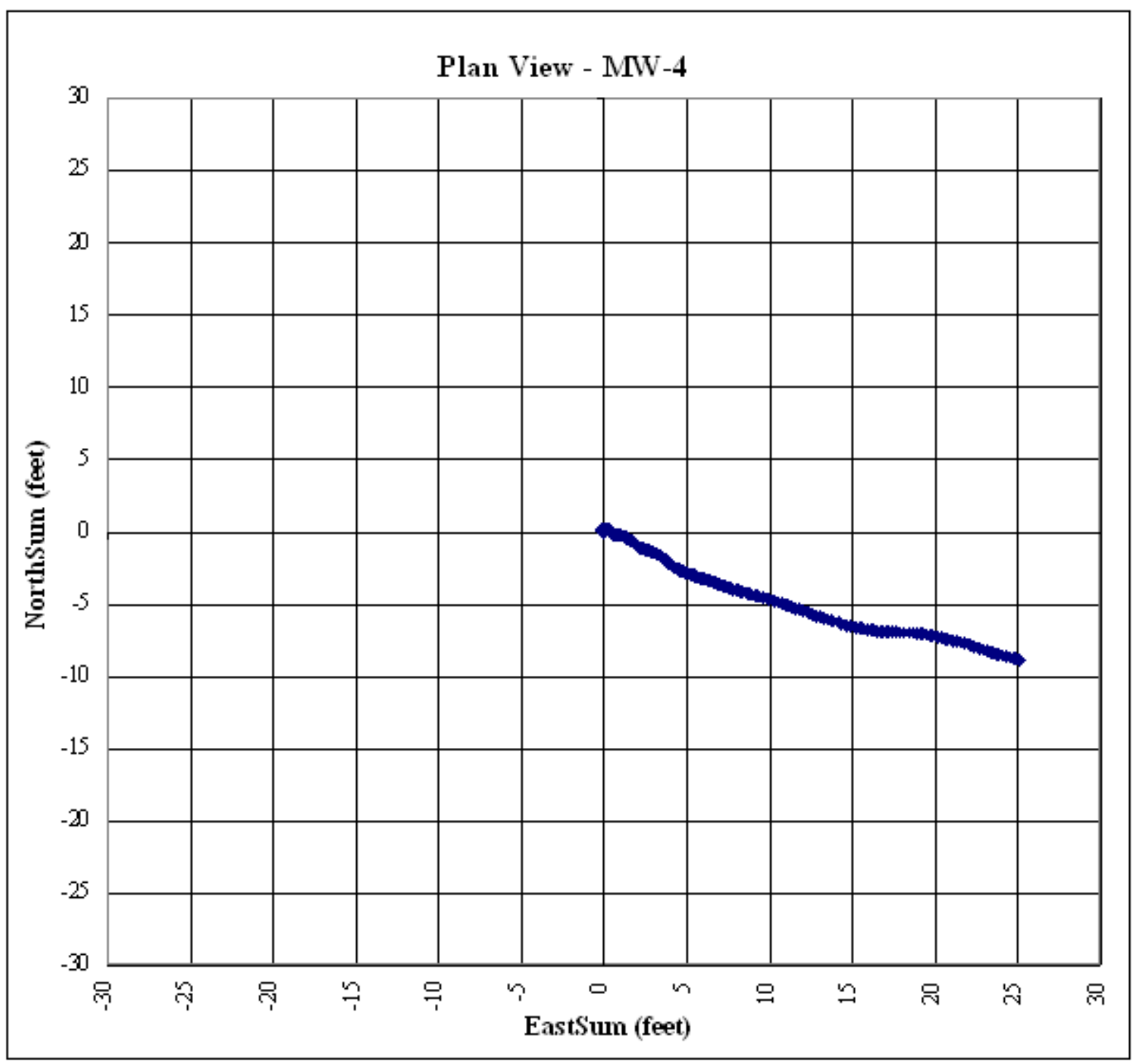

Figure 4-3. Deviation Plot for Well MV-4

\subsection{Sampling}

Geologic material and water quality samples were collected during the advancement of the borehole, construction of the well and piezometer, and development of the well and piezometer. Samples included rock cuttings for lithologic description, and drilling fluid and groundwater for water quality analysis. Samples were collected according to the FMP (DOE 2009a) and FI (DOE 2009c). The following sections summarize the sampling activities.

\subsubsection{Geologic Material Sampling}

Samples of the drill cuttings were collected during the advancement of the borehole. The rock cuttings were collected from the drill rig shaker screen, washed, and composited for 10-ft intervals. The lithologic units encountered during the drilling are summarized below. Included at 
the end of Appendix B is a monitor well completion log with a lithologic log of the samples collected from the MV-4 borehole.

QTa (Quaternary and Tertiary alluvium)

$\underline{0-1,590 \mathrm{ft}:}$ This section is composed of alluvium and valley-fill deposits containing silt and clay, sand, gravel, cobbles, and boulders. The rock fragments in the alluvium predominantly contain subangular to subrounded clasts, with minor amounts of angular and rounded clasts. The angular clasts appear to outnumber the rounded clasts within these drill cuttings, but it is possible that this distribution based on clast rounding has been altered by the drilling process wherein the drill bit creates more angular clasts by breaking up larger rounded and subrounded clasts. The clasts themselves are composed almost entirely of densely welded rhyolitic and latitic tuff and very minor dark gray limestone and dolomite derived from the surrounding mountains. Although nonwelded to partly welded tuffs also occur within the surrounding mountains, these softer rocks typically are eroded away by flash floods on the surface of the alluvial fan and, thus, are underrepresented in these deposits. Concentrations of lithic clasts vary laterally and vertically, with silty and clayey layers interbedded with sandy and gravelly layers. Samples of drill cuttings from the valley-fill alluvium typically contain coarser detritus (gravel-size clasts and larger) in a matrix of silt and clay. While this may reflect the poorly sorted nature of alluvial deposits, some beds within the alluvium can be quite well sorted.

\section{Fault}

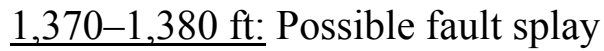

1,400-1,410 ft: Fault. At these fault intervals, the drill cutting samples were dominated by clay, with minor amounts of sand and gravel for 1,370-1,380 ft, and minor amounts of sand for 1,400-1,410 ft. The geolograph chart recorded, in addition to the clay-rich samples, considerable torque on the drill bit when these intervals were drilled. In fact, these two intervals recorded more torque during the drilling than any other part of MV-4. Since these two intervals were at the general depth at which the southeast bounding graben fault was projected to intercept the borehole, they have been interpreted as fault zones. The lower fault zone at 1,400-1,410 $\mathrm{ft}$ is considered the main fault; the upper interval at 1,370-1,380 $\mathrm{ft}$ is considered a possible fault splay within the hanging wall of the main fault. The deviation survey confirms that the borehole deviates from vertical by a greater amount below the faults than it does above the fault. However, given that the deviation survey fails to show an inflection point where the deviation suddenly increases, and that the borehole deviates into the direction of the fault, borehole deviation in MV-4 may be completely independent of any buried structures. None of the downhole geophysical logs show anything unique at the depths these faults were intercepted by the borehole.

QTa/Tvtr transition zone (Quaternary and Tertiary alluvium/Tertiary volcanic and volcaniclastic deposits, undifferentiated)

1,590-2,120 ft: This interval is marked as a transition zone from sediments that appear to be composed entirely of alluvium to sediments that contain significant amounts of volcanic and epiclastic deposits. The transition from alluvium composed primarily of volcanic rocks to alluvium containing significant proportions of volcaniclastic and tuffaceous sediments is quite subtle and often difficult to identify. This section contains welded and nonwelded tuff, reworked tuff, interbedded tuffaceous sandstone and conglomerate, and lacustrine siltstone and mudstone. The beds described in the lithologic log as reworked tuff, tuffaceous sandstone and conglomerate could also represent interbedded alluvium. At least three of the tuffs encountered in this section 
are thin welded tuffs. Although similar lithologies are observed in the adjacent Squaw Hills, those particular volcanic and volcaniclastic strata are part of the Tuffaceous rocks of Slanted Butte and have been positively correlated with deeper strata in drill holes MV-1, MV-2, and MV-3, as well as tentatively identified in drill hole UCE-17. However, rocks stratigraphically equivalent to the volcanic and volcaniclastic beds of unit Tvtr in MV-4 have not been identified in the adjacent mountain ranges, and it is likely that these strata were long ago removed from the adjacent mountains by erosion. At the depth of 2,120 ft, sediments encountered during drilling appeared to be primarily tuffaceous sediments.

\subsubsection{Radiological Sampling and Monitoring}

Samples of the drilling fluid, source water, and groundwater discharged during development were collected and analyzed on site for tritium. Samples obtained during the drilling operations were collected at approximately 30 -ft intervals or every hour from below the cyclone as the fluid entered the mud tank. Samples obtained during the development were collected from the discharge line approximately every 2 hours. Samples collected and analyzed during the drilling, construction, and development of well MV-4 indicated concentrations of tritium below the U.S. Environmental Protection Agency (EPA) maximum contaminant level (MCL) of $20,000 \mathrm{pCi} / \mathrm{L}$ and the notification level $(10,000 \mathrm{pCi} / \mathrm{L})$ established in the FMP. A few sample analyses initially indicated detectable concentrations of tritium, but when the samples were reanalyzed, with close adherence to the procedure of limiting their exposure to light prior to analysis; the results were within background ranges. Table B-3 in Appendix B provides the tritium results obtained during the drilling and development of well MV-4.

\subsubsection{Bromide and Water Quality Sampling}

Samples of the drilling fluid, source water, and groundwater discharged during development were collected and analyzed to monitor $\mathrm{pH}$, temperature, specific conductance, bromide, and turbidity. Samples obtained during the drilling operations were collected at approximately $30-\mathrm{ft}$ intervals or every hour from below the cyclone as the fluid entered the mud tank. Samples obtained during the development were collected from the discharge line approximately every 2 hours. Concentrations of bromide in the drilling fluid ranged from 11 to $25 \mathrm{mg} / \mathrm{L}$ during the drilling operations, from 1.7 to $27 \mathrm{mg} / \mathrm{L}$ during development using the airlifting method, and from 0.8 to $8.2 \mathrm{mg} / \mathrm{L}$ during development using an electric submersible pump. Section 4.4 summarizes the well development activities. Refer to Figure 4-4 for a chart of the results obtained during the drilling and well development. Refer to Table B-4 in Appendix B for the groundwater quality parameter and bromide results obtained during the drilling and development of well MV-4.

\subsection{Initial Well Development}

The initial development of well MV-4 began on May 5, 2009. This development consisted of airlifting and was performed with the LM 300E drill rig using a 1,100 cubic feet per minute (cfm) air compressor plumbed to an AQ airline with HQ eductor. The initial development included approximately 22 hours of airlifting and surging. Fluid discharge rates averaged approximately 9 gallons per minute (gpm) during the development. The fluid discharge rates decreased to approximately $6 \mathrm{gpm}$ at the completion of the airlift development. Concentrations of bromide obtained from samples analyzed during the development ranged from $12 \mathrm{mg} / \mathrm{L}$ at 
startup to $5.7 \mathrm{mg} / \mathrm{L}$ at completion. A total of approximately 11,400 gallons of fluid were removed during the initial airlift development of MV-4.

The development of the MV-4 piezometer began on May 7, 2009. The airlift development was performed for approximately 12 hours with the LM 300E drill rig using a 1,100 cfm air compressor plumbed to a 0.5 -inch airline. Fluid discharge rates from the piezometer averaged approximately $22.5 \mathrm{gpm}$. The development of the piezometer was completed on May 7, 2009. Concentrations of bromide obtained from samples analyzed during the development ranged from $27 \mathrm{mg} / \mathrm{L}$ at startup to $3.8 \mathrm{mg} / \mathrm{L}$ at completion. A total of approximately 9,000 gallons of fluid were removed from the piezometer during the development of well MV-4.

The second phase of airlift development was conducted at well MV-4 on May 8, 2009. This phase of development was conducted with the LM 300E drill rig and included approximately 20 hours of airlifting and surging. Fluid discharge rates averaged approximately 4.3 gpm during the development but decreased to approximately $3 \mathrm{gpm}$ at completion. Concentrations of bromide obtained from samples analyzed during the development ranged from $6.4 \mathrm{mg} / \mathrm{L}$ at startup to $1.8 \mathrm{mg} / \mathrm{L}$ at completion. A total of approximately 4,000 gallons of fluid were removed during the second phase of airlift development at well MV-4.

\subsection{Pump Installation and Final Well Development}

Well MV-4 was completed with the 4-inch stainless-steel submersible Grundfos pump, model 10S50-58DS, with a 5-horsepower Grundfos motor removed from well MV-3. The installation of the dedicated submersible electric pump began on May 25, 2009. The pump was installed using the LX-29 pump rig, and the installation included setting the pump, riser pipe, and water-access tube. The installation of the pump was completed on May 26, 2009. The intake of the pump was set at approximately 1,711 ft bgs. The pump is powered by an MS 4000, 5-horsepower, 480-volt, three-phase Grundfos motor. Power is supplied to the pump using number-2 AWG 600-volt, heavy-duty, flat submersible cable that is banded and clamped to the 1-inch OD carbon-steel API pipe with external upset ends (EUE). The water-access tube is also banded and clamped to the 1-inch OD pump discharge pipe. The water-access tube is constructed with 1.25-inch-OD schedule-80 polyvinyl chloride (PVC) pipe with flush joints. The wateraccess tube is completed with $40 \mathrm{ft}$ of 0.02 -inch screen that is set just above the top of the pump. Table B-2 in Appendix B provides the pump and tubing specifications used to complete well MV-4.

The final development of well MV-4 was performed using the dedicated pump and began on May 27, 2009. Well development was performed during daytime operations and included approximately 71 hours of continuous pumping. Results obtained from the final sample collected during the well development indicated concentrations of bromide at $0.9 \mathrm{mg} / \mathrm{L}$, turbidity of 3 nephelometric turbidity units (NTU), and tritium below background. Well development was completed on June 3, 2009. Fluid discharge rates averaged approximately $6 \mathrm{gpm}$, and approximately 25,200 gallons of fluid were removed during the development of well MV-4. Refer to Figure 4-4 for a graph comparing bromide concentrations to gallons removed during the development of well MV-4. 


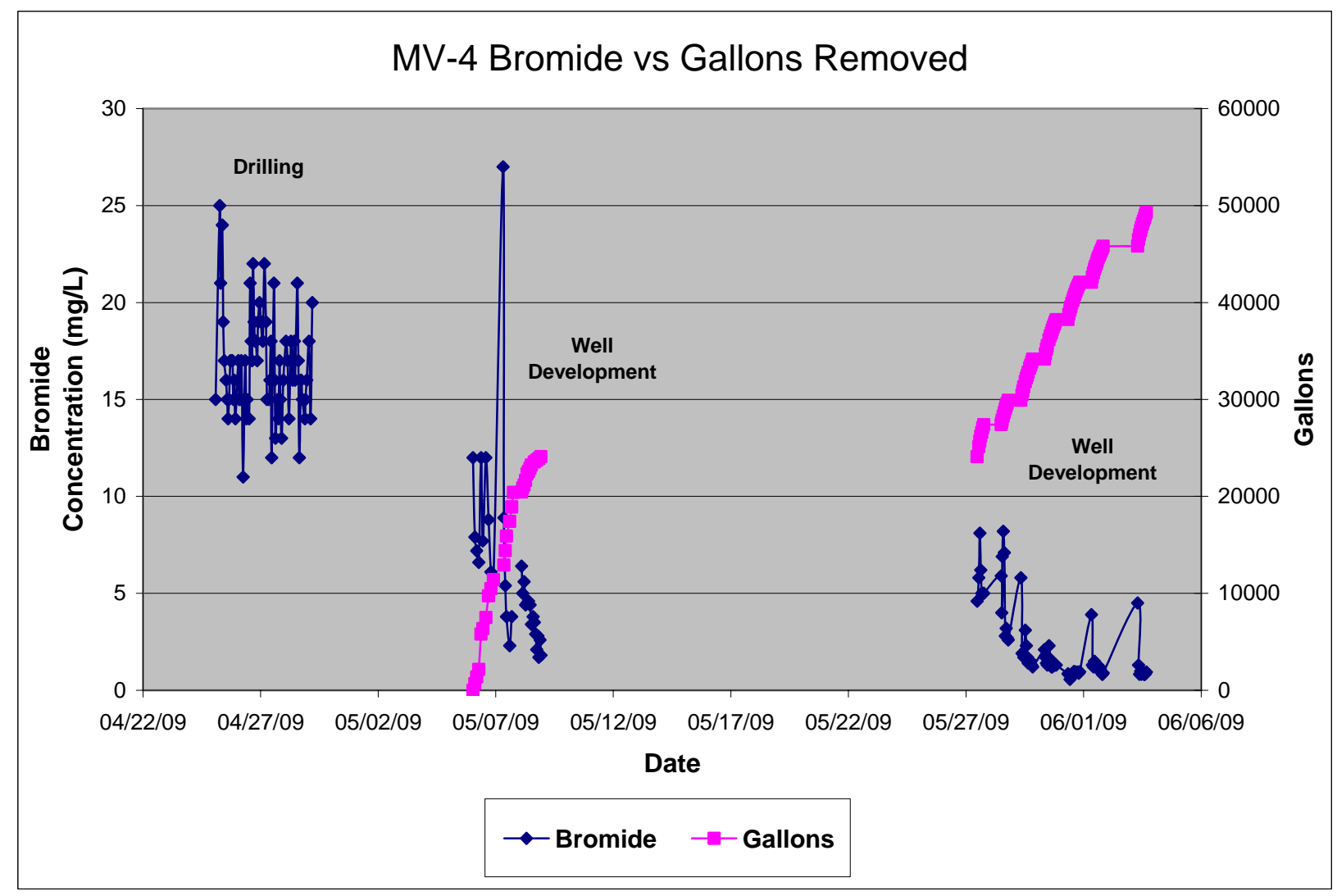

Figure 4-4. MV-4 Bromide versus Gallons Removed 


\subsection{Summary of Well MV-5 Activities}

Well MV-5 was the second of two new wells constructed at CNTA. This well was drilled and completed approximately 1,200 ft southeast of SGZ (Figure 1-2). The drilling of the initial borehole began on May 10, 2009. The borehole was completed to the total depth of 2,400 ft bgs on May 16, 2009. Geophysical logging of the borehole was conducted in two phases. The first phase was conducted from 100 to 2,400 ft bgs and began on May 16, 2009. The second phase was conducted during the installation of the well and piezometer filter pack materials, and began on May 20, 2009. The piezometer and well construction was completed on May 22, 2009, to depths of 1,097.35 and 2,203.44 ft bgs, respectively. Initial airlift development of the well and piezometer was completed on May 25, 2009. A dedicated pump was installed, and final well development took place, from June 4 through June 9, 2009. The following sections summarize the well construction, geophysical well logging, sampling, well development, and pump installation activities. Refer to Table $\mathrm{C}-1$ in Appendix $\mathrm{C}$ for a chronology of the drilling operations at well MV-5.

\subsection{Well Drilling and Construction}

The installation of well MV-5 included drilling an initial 31-inch-diameter borehole to a depth of $100 \mathrm{ft}$ bgs to allow a 24-inch-OD carbon-steel casing with fully welded joints to be installed as a surface seal and wellhead control apparatus. This casing was set to a depth of $100 \mathrm{ft}$ bgs and cemented in place using approximately $210 \mathrm{ft}^{3}$ of Portland Type II cement. The final borehole was drilled from $100 \mathrm{ft}$ to the total depth of 2,400 ft bgs using a 12.25-inch tricone button bit. The borehole was plugged back from 2,400 to 2,232 ft bgs with cement upon completion of the geophysical well logging. The selection of well and piezometer screen intervals was based on geologic data collected while drilling (cuttings, drill rates) and the geophysical logs.

Well MV-5 was completed with a well and piezometer in the 12.25-inch borehole. The well consisted of a 5.5-inch-OD internally ceramic-coated carbon-steel casing. The well was screened from 1,838.57 to 2,163.00 ft bgs with manufactured 3-by-0.078-inch slotted openings on 6-inch centers staggered at 10 degrees with 18 slots per row. The well was completed to a total depth of 2,203.44 ft bgs, which included approximately $40 \mathrm{ft}$ of blank casing below the well screen for a sump. Eight centralizers were placed around the well screen at approximately 40 -ft intervals to ensure proper spacing of filter pack materials. The piezometer was constructed with 2.375-inchOD carbon-steel casing with $60 \mathrm{ft}$ of slotted (0.078-inch interval) screen installed from $1,017.70$ to $1,077.70 \mathrm{ft}$ bgs. The piezometer was completed to a total depth of 1,097.35 ft bgs and included approximately $20 \mathrm{ft}$ of blank casing below the well screen for a sump. Two centralizers spaced approximately $40 \mathrm{ft}$ apart were placed around the well casing at the depth of the piezometer screened interval to ensure proper spacing of filter pack materials.

A graded filter pack was installed around the slotted intervals of the well and piezometer. Filter pack materials for MV-5 included 1/8- to $1 / 4$-inch clean gravel and No. 6 clean silica sand. A seal of $3 / 8$-inch bentonite chips was placed above the filter pack. The gravel filter pack was placed around the well and piezometer screen intervals, and the No. 6 silica sand was placed above the gravel. Gravel, sand, and bentonite chips were placed using a sand pump with a clean-water flush into the borehole annulus through an NQ tremie pipe. Portland Type II cement was used to seal the annulus above the filter pack and bentonite seal well to 1,120 ft bgs, about $20 \mathrm{ft}$ below the base of the piezometer. Cement was also pumped down the NQ tremie, followed by a clean- 
water rinse. The NQ tremie was raised in stages during the placement of the stemming materials to help ensure proper placement without plugging or bridging. COLOG monitored the placement of stemming materials in real time, using a NAIL, to verify correct tagging depths. Table $\mathrm{C}-2$ in Appendix C lists well construction materials and volumes used to complete MV-5. Refer to Figure 5-1 for a diagram showing well construction details of MV-5.

\subsection{Geophysical Well Logging}

COLOG acquired borehole geophysical logs from the MV-5 borehole in two separate phases. The first phase of the geophysical logging was performed in the 12.25-inch-diameter borehole from below the surface casing (100 ft) to the completion depth of approximately 2,400 ft bgs. This phase of the logging suite included caliper, neutron (epithermal and compensated), natural gamma ray, spontaneous potential, deviation, formation density, resistivity (dual laterolog/dual induction), temperature, and sonic velocity logs. The first phase of logging was completed on May 18, 2009. Refer to Figure 5-2 for a condensed version of the geophysical logs obtained from well MV-5.

The second phase of the logging was performed in the well and included a NAIL. This phase of the logging was completed on May 21, 2009. The NAIL was used for the real-time tagging of stemming materials during well construction. A borehole deviation survey performed within the borehole provided the extent the well deviated from vertical. The deviation survey indicated that the bottom of the borehole had deviated less than 1 degree from vertical, placing the bottom of the borehole and bottom of the well approximately $25.40 \mathrm{ft}$ and $20.7 \mathrm{ft}$ south-southeast from the surface collar, respectively. Refer to Figure 5-3 for a deviation plot of the MV-5 borehole. 


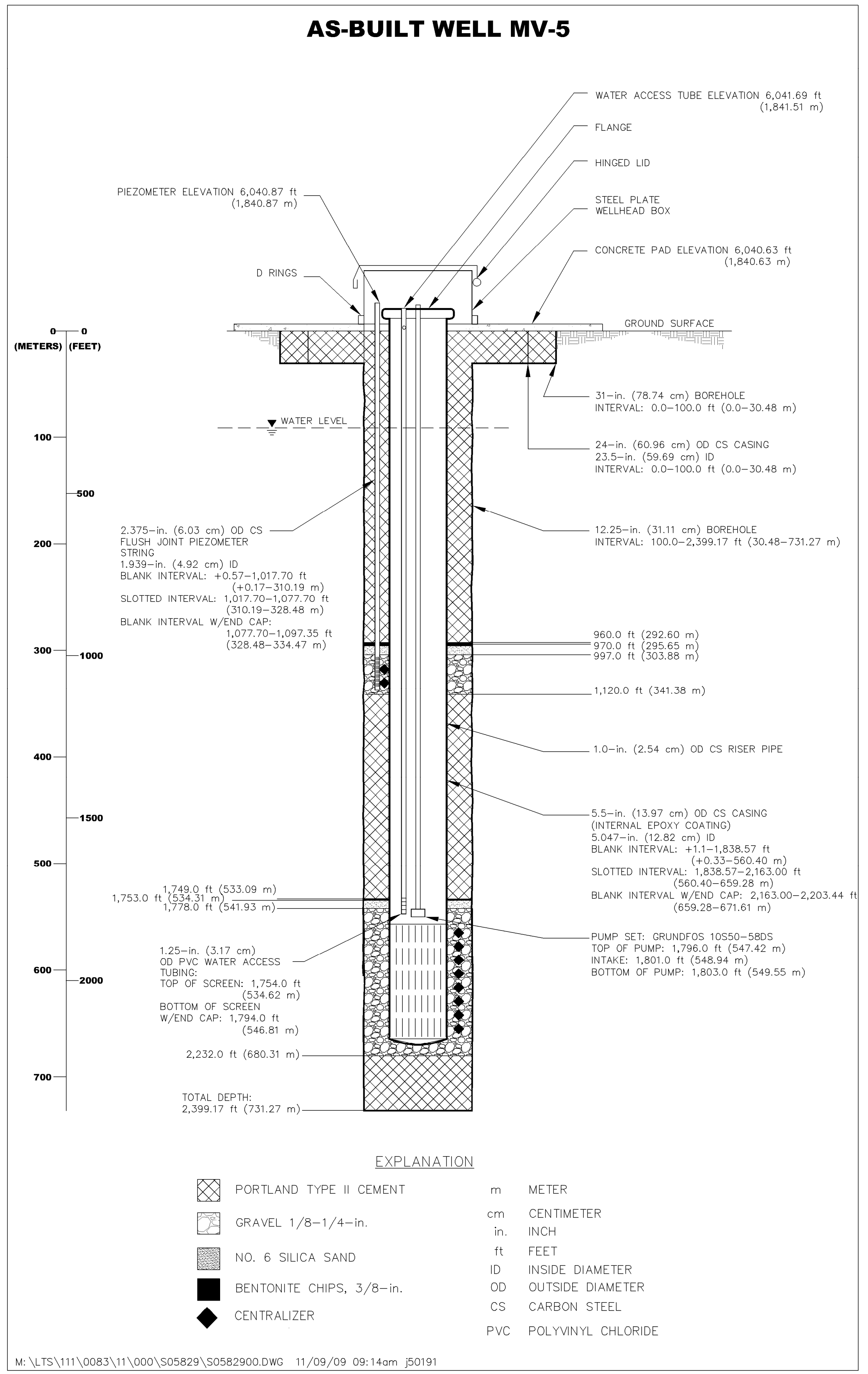

Figure 5-1. As-Built Well MV-5 
This page intentionally left blank 

MV-5 Geophysical Logs Resistivity (ohms)

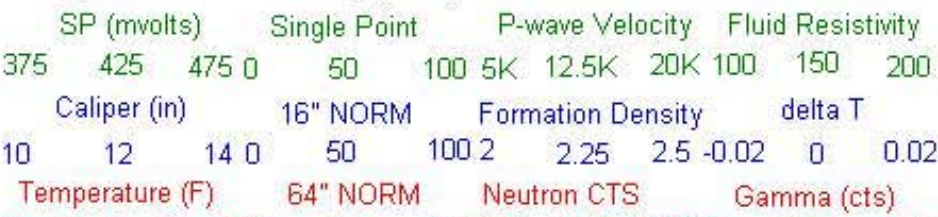

$\begin{array}{lllllllllllll}\text { Ft } & 15 & 20 & 25 & 30 & 350 & 50 & 100500 & 1000 & 1500 & 0 & 100 & 200\end{array}$
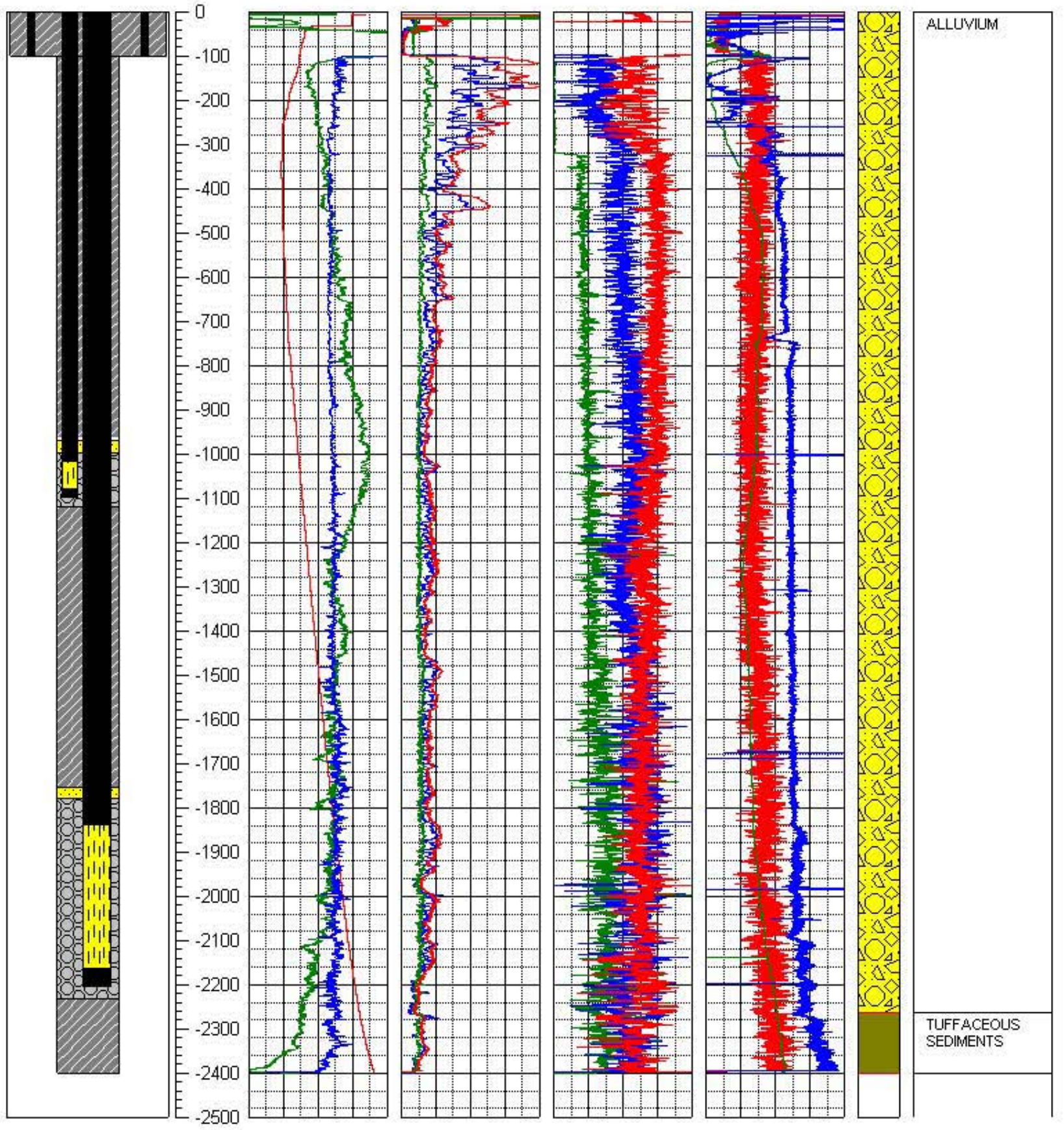

Figure 5-2. MV-5 Geophysical Logs 


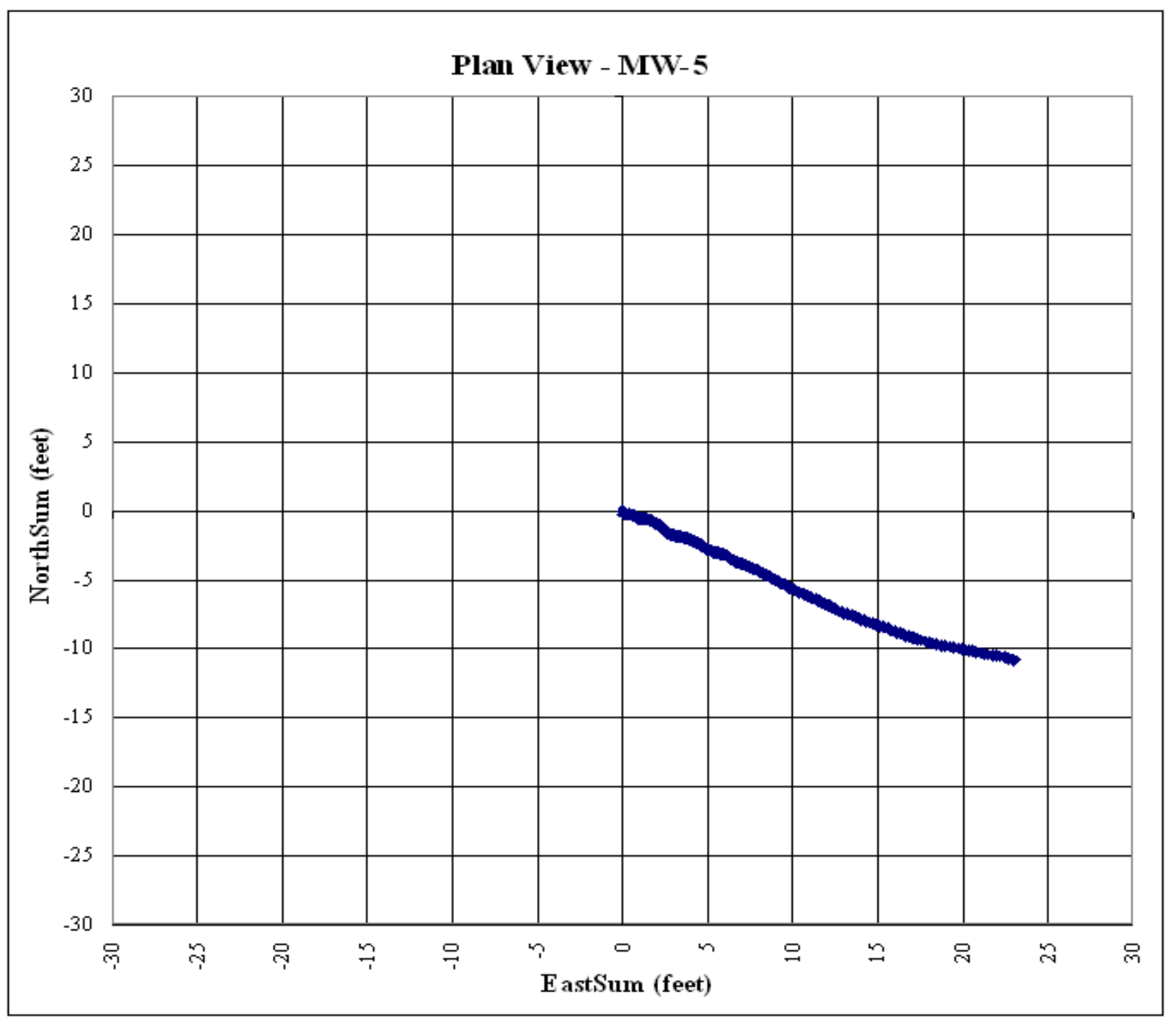

Figure 5-3. Deviation Plot of Well MV-5

\subsection{Sampling}

Geologic material and water quality samples were collected during the advancement of the borehole, construction of the well and piezometer, and development of the well and piezometer. Samples included rock cuttings, for lithologic description, and drilling fluid and groundwater, for water quality analysis. Samples were collected according to the FMP (DOE 2009a) and FI (DOE 2009c). The following sections summarize the sampling activities. 


\subsubsection{Geologic Material Sampling}

Samples of the drill cuttings were collected during the advancement of the borehole. The rock cuttings were collected from the drill rig shaker screen, washed, and composited for 10-ft intervals. The lithologic units encountered during the drilling are summarized below. Included at the end of Appendix $\mathrm{C}$ is a monitor well completion log with a lithologic log of the samples collected from the MV-5 borehole.

QTa (Quaternary and Tertiary alluvium)

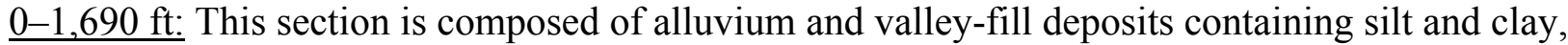
sand, gravel, cobbles, and boulders. The rock fragments in the alluvium predominantly contain subangular to subrounded clasts, with minor amounts of angular and rounded clasts. The angular clasts appear to outnumber the rounded clasts within these drill cuttings, a bias likely resulting from the drilling process. The clasts themselves are composed almost entirely of densely welded rhyolitic and latitic tuff and very minor dark gray limestone and dolomite derived from the surrounding mountains. Nonwelded to partly welded tuffs, similar to those cropping out in the surrounding mountains, are underrepresented in this alluvium because these soft rock types are easily weathered away. Concentrations of lithic clasts vary laterally and vertically, with silty and clayey layers interbedded with sandy and gravelly layers. Samples of drill cuttings from the valley-fill alluvium typically contain coarser detritus (gravel-size clasts and larger) within a matrix of silt and clay. While this typically reflects the poorly sorted nature of alluvial deposits in general, some well-sorted beds exist within this sequence of predominantly poorly sorted strata.

\section{Fault}

A depth for the intercept of the fault by borehole MV-5 was not determined, even though the borehole likely intercepted the plane of the fault that defines the CNTA collapse graben. Although several clay-rich samples were collected from various depths in MV-5, none of them correlated with drilling breaks characterized by the high torque levels observed in the faulted zones in MV-4. Furthermore, the deviation survey for MV-5 revealed that it was a slightly straighter hole than MV-4, and lacked inflection points where the rate of deviation suddenly increased. Although several discrete depths manifest small geophysical anomalies that rise slightly above the background level of fluctuations on the geophysical logs, none of them correlate with discrete intervals dominated by clay.

QTa/Tvtr transition zone (Quaternary and Tertiary alluvium/Tertiary volcanic and volcaniclastic deposits, undifferentiated)

1,690-2,260 ft: This interval marks the transition from sediments that appear to be composed entirely of alluvium to sediments that contain significant amounts of volcanic and epiclastic deposits. The transition from alluvium composed primarily of volcanic rocks to alluvium containing significant proportions of volcanic and volcaniclastic rocks is subtle and difficult to identify. This section is composed of welded and nonwelded tuff, reworked tuff, interbedded tuffaceous sandstone, and conglomerate. The beds described in the lithologic log as reworked tuff, tuffaceous sandstone, and conglomerate could also represent interbedded alluvium. At least four of the tuffs encountered in this section are thin welded tuffs. Although similar lithologies are observed in the adjacent Squaw Hills, those particular volcanic and volcaniclastic strata are part of the Tuffaceous rocks of Slanted Butte and have been positively correlated with deeper strata in drill holes MV-1, MV-2, and MV-3, as well as tentatively identified in drill hole UCE-17. However, rocks stratigraphically equivalent to the volcanic and volcaniclastic beds of unit Tvtr 
in MV-5 have not been identified in the adjacent mountain ranges because they were removed from there by erosion. At the depth of $2,260 \mathrm{ft}$, sediments encountered during drilling appear to be primarily tuffaceous sediments.

\subsubsection{Radiological Sampling and Monitoring}

Samples of the drilling fluid, source water, and groundwater discharged during development were collected and analyzed for tritium on site. Samples obtained during the drilling operations were collected at approximately $30-\mathrm{ft}$ intervals or every hour from below the cyclone as the fluid entered the mud tank. Samples obtained during the development were collected from the discharge line approximately every 2 hours. Samples collected and analyzed during the drilling of well MV-5 generally indicated concentrations of tritium below the EPA MCL of 20,000 pCi/L and the notification level $(10,000 \mathrm{pCi} / \mathrm{L})$ established in the FMP. An exception was the sample collected during the drilling at 2,290 ft bgs on May 27, 2009. This sample initially indicated a tritium concentration of $22,972 \mathrm{pCi} / \mathrm{L}$. The sample was reanalyzed, additional samples were collected, and drilling was suspended. The additional samples and reanalysis provided results that were at or below background levels. The false positive was attributed to excessive light exposure during the analysis process, and drilling resumed. All remaining samples collected and analyzed for tritium during the drilling and development were below the EPA and FMP action levels. Table C-3 in Appendix C provides the tritium results obtained during the drilling and development of well MV-5.

\subsubsection{Bromide and Water Quality Sampling}

Samples of the drilling fluid, source water, and groundwater discharged during development were collected and analyzed to monitor $\mathrm{pH}$, temperature, specific conductance, bromide, and turbidity. Samples obtained during the drilling operations were collected at approximately $30-\mathrm{ft}$ intervals or every hour from below the cyclone as the fluid entered the mud tank. Samples obtained during the development were collected from the discharge line approximately every 2 hours. Concentrations of bromide in the drilling fluid ranged from 27 to $54 \mathrm{mg} / \mathrm{L}$ during the drilling operations, from 2.6 to $34 \mathrm{mg} / \mathrm{L}$ during development using the airlifting method, and from 1 to $11 \mathrm{mg} / \mathrm{L}$ during development using an electric submersible pump. Section 5.4 summarizes the well development activities. Refer to Figure 5-4 for a chart of the results obtained during the drilling and well development. Table $\mathrm{C}-4$ in Appendix $\mathrm{C}$ provides the groundwater quality parameter and bromide results obtained during the drilling and development of well MV-5.

\subsection{Initial Well Development}

The initial development of well MV-5 began on May 22, 2009. This development consisted of airlifting and was performed with the LM 300E drill rig using a 1,100 cfm air compressor plumbed to an AQ airline with HQ eductor. The initial development included approximately 36 hours of airlifting and surging. Fluid discharge rates averaged approximately 10.5 gpm during the development. The fluid discharge rates decreased to approximately $8 \mathrm{gpm}$ at the completion of the airlift development. Concentrations of bromide obtained from samples analyzed during the development ranged from $34 \mathrm{mg} / \mathrm{L}$ at startup to $2.6 \mathrm{mg} / \mathrm{L}$ at completion. A total of approximately 14,000 gallons of fluid were removed during the airlift development of well MV-5. 


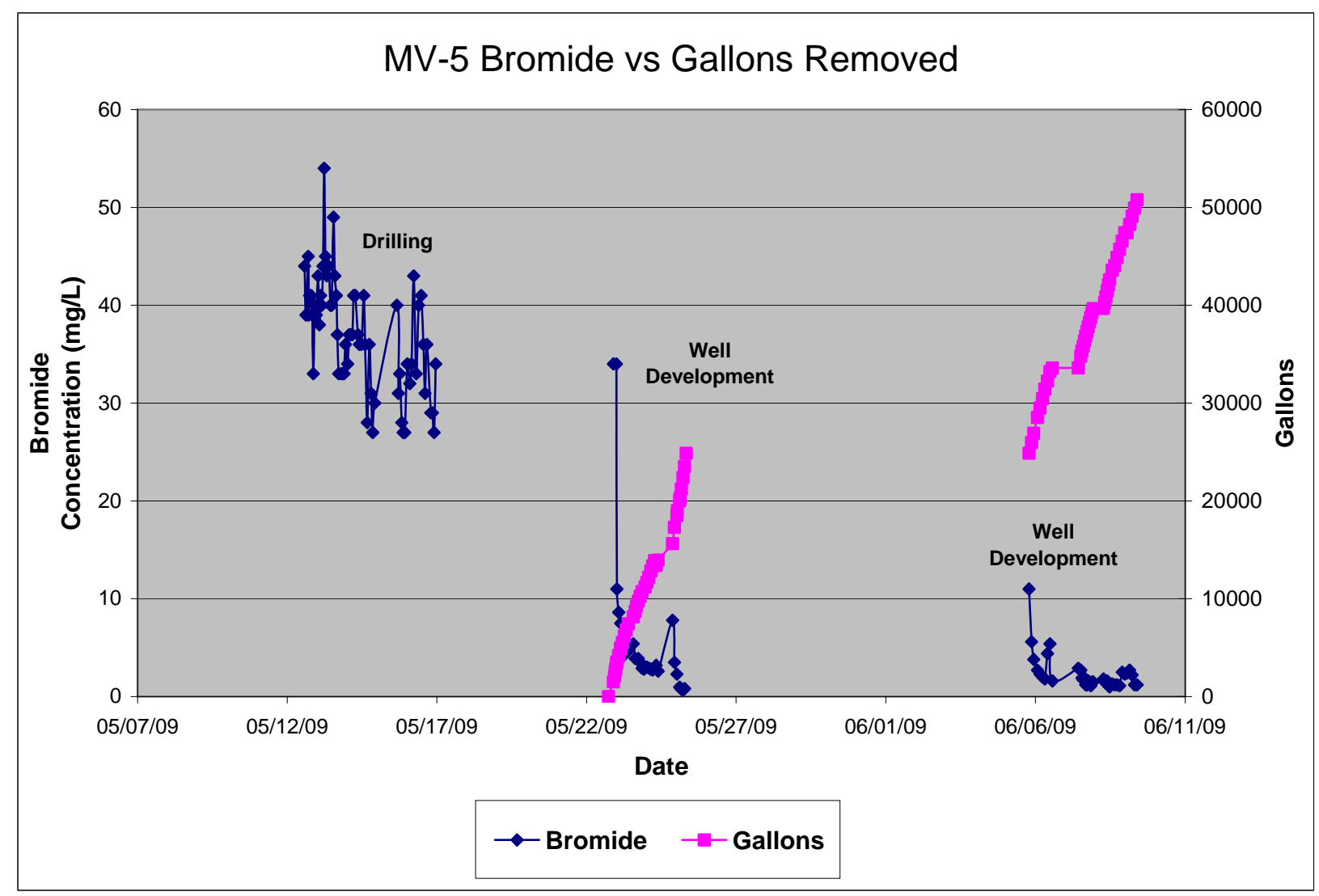

Figure 5-4. MV-5 Bromide versus Gallons Removed

The development of the MV-5 piezometer began on May 24, 2009. The airlift development was performed for approximately 12 hours with the LM 300E drill rig using a 1,100 cfm air compressor plumbed to a 0.5 -inch airline. Fluid discharge rates from the piezometer averaged approximately $18.5 \mathrm{gpm}$. The development of the piezometer was completed on May 25, 2009. Concentrations of bromide obtained from samples analyzed during the development ranged from $7.8 \mathrm{mg} / \mathrm{L}$ at startup to $0.97 \mathrm{mg} / \mathrm{L}$ at completion. A total of approximately 11,000 gallons of fluid were removed from the piezometer during the development of well MV-5.

\subsection{Pump Installation and Final Well Development}

Well MV-5 was completed with the 4-inch stainless-steel submersible Grundfos pump, model 10S50-58DS, with a 5-horsepower Grundfos motor that was removed from well MV-1. The installation of the dedicated submersible electric pump began on June 4, 2009. The pump was installed using the LX-29 pump rig, and the installation included setting the pump, riser pipe, and water-access tube. The installation of the pump was completed on June 5, 2009. The intake of the pump was set at approximately 1,801 ft bgs. A new MS 4000 5-horsepower, 480-volt, three-phase Grundfos motor now powers the pump because the original motor from the MV-1 well failed. Power is supplied to the pump using number-8 AWG 600-volt, heavy-duty, flat submersible cable that is banded and clamped to the 1-inch OD carbon-steel API pipe with EUE. The water-access tube is also banded and clamped to the 1-inch OD pump discharge pipe. The 
water-access tube is constructed with 1.25 -inch-OD schedule- 80 PVC pipe with flush joints. The water-access tube is completed with $40 \mathrm{ft}$ of 0.02 -inch screen that is set just above the top of the pump. Refer to Table $\mathrm{C}-2$ in Appendix $\mathrm{C}$ for the pump set specifications associated with well MV-5.

The final development of well MV-5 was performed using the dedicated pump and began on June 4, 2009. The well development was performed during daytime operations and included approximately 56 hours of continuous pumping. Sample results obtained from the final sample during the development indicated bromide concentrations of $1.2 \mathrm{mg} / \mathrm{L}$, turbidity of $11.8 \mathrm{NTU}$, and tritium below background. The well development was completed on June 9, 2009. Fluid discharge rates averaged approximately $8 \mathrm{gpm}$, and approximately 26,000 gallons of fluid were removed during the development of well MV -5. Refer to Figure 5-4 for a graph comparing bromide concentrations to gallons removed during the development of well MV-5. 


\subsection{Summary of Well UC-1-P-1SRC Activities}

Well UC-1-P-1S was the first of the two existing wells to be recompleted during the drilling program at CNTA. This well was originally completed in February 1968, shortly after the underground nuclear test, and is approximately 1,250 ft southeast of SGZ (Figure 1-2). Initially, the well was constructed within a 10.75-inch-OD carbon-steel casing that was completed in a 15-inch borehole to a depth of $525 \mathrm{ft}$. The borehole was then reduced to 9.875 inches and extended to a total depth of 2,734 ft bgs. At that depth, the drill bit and rods twisted off and could not be recovered. The borehole could not be completed as planned, and the borehole-with drill rods - was cemented to the top of the drill pipe at a depth of $964 \mathrm{ft}$ bgs. The well was then completed without filter pack materials, with 4.5-inch-OD carbon-steel casing to a depth of $922 \mathrm{ft}$ bgs. To evaluate this well as a future monitoring location, geophysical well logs were obtained in October 2008. The geophysical well logs indicated that the casing had deteriorated. It was recommended that the casing be replaced. Section 6.2 summarizes the geophysical well logging activities.

The recompletion of well UC-1-P-1S included several attempts to remove the old 4.5-inch casing from May 23 through May 31, 2009. During this time, approximately $600 \mathrm{ft}$ of the old casing was removed from the borehole. Approximately $320 \mathrm{ft}$ of the old casing could not be removed below a depth of $601 \mathrm{ft}$ bgs, and the decision was made to recomplete the well with new casing to a depth of $573.78 \mathrm{ft}$ bgs. The new casing was installed on June 2, 2009. Airlift development was conducted on June 3 and 4, 2009. Following the installation of a pump and water-access tubing on June 6, 2009, purging development was conducted on June 9, 2009. Upon recompletion of well UC-1-P-1S, the location identification was changed to UC-1-P-1SRC. The following sections summarize the well construction, geophysical well logging, pump installation, and development activities. Refer to Table D-1 in Appendix D for a chronology of the recompletion activities at well UC-1-P-1SRC.

\subsection{Well Construction}

The recompleted well UC-1-P-1SRC was constructed within the existing 10.75-inch-OD carbonsteel casing with 5.5-inch-OD internally ceramic-coated carbon-steel casing. The 10.75-inch casing extends to a depth of $525 \mathrm{ft}$ bgs, and the new 5.5-inch casing was completed to $573.78 \mathrm{ft}$ bgs inside the 9.875-inch borehole. The well was screened from 512.04 to $573.02 \mathrm{ft}$ bgs with $60 \mathrm{ft}$ of manufactured 0.078-inch slotted casing. A cement plug or seal was set below the well from 584 to $626 \mathrm{ft}$ bgs. Refer to Figure 6-1 for a diagram showing well construction details of UC-1-P-1SRC.

A graded filter pack was installed around the slotted interval of the recompleted well UC-1-P-1SRC. Filter pack materials included 1/8- to 1/4-inch clean gravel and No. 6 clean silica sand. The clean gravel was placed above the cement seal in the annulus between the well screen and the old 9.875-inch borehole and 10.75-inch intermediate casing. The gravel pack extended slightly above the well screen, and the No. 6 silica sand was placed above the gravel pack as transition sand. A seal of $3 / 8$-inch bentonite chips was placed above the gravel and sand filter pack. Gravel, sand, and bentonite chips were placed using a sand pump with a clean-water flush through a BQ tremie pipe. Portland Type II cement was used to seal the annulus to the surface above the filter pack and bentonite. Cement was also pumped down the BQ tremie, followed by a clean-water rinse. The BQ tremie was raised in stages during placement of the stemming 
materials to help ensure proper placement without plugging or bridging. Table $\mathrm{D}-2$ in Appendix D lists the well construction materials and volumes used to recomplete well UC-1-P-1SRC.

\subsection{Geophysical Well Logging}

The decision to recomplete the existing well UC-1-P-1S was based on geophysical logs obtained before the drilling program began at CNTA. Schlumberger collected the geophysical logs on October 16, 2008. The objective of logging the well was to evaluate the integrity of the well casing for use as a future sample location of groundwater in the upper alluvium. It was concluded, based on the geophysical logs, that the 4.5-inch steel casing in well UC-1-P-1S was very deteriorated and should be replaced.

The existing well UC-1-P-1S was logged using an assembled tool string approximately $19.7 \mathrm{ft}$ long. The bottom of the tool string was lowered to a depth of $855 \mathrm{ft}$ bgs, below which the well was plugged with sediment. The depth-to-water in the well was approximately $274 \mathrm{ft}$ bgs, and the bottom of the logged interval for the well was $851.4 \mathrm{ft}$ bgs. A Production Multi-Finger Imaging Tool (PMIT), or caliper imaging tool, and a gamma ray-collar log were run in this well. After the caliper log was run and removed from the well, the ends of the numerous fingers on the caliper tool had rusty and greasy black material on them. The PMIT log showed that the 4.5-inch steel casing was corroded and out of gauge below the water level (274 ft bgs). The slotted 4.5-inch steel casing was hung in the borehole without filter pack materials or cement. Refer to the end of Appendix D for a copy of the geophysical well logs obtained from well UC-1-P-1S.

\subsection{Sampling}

Water samples were collected as part of the recompletion of well UC-1-P1SRC. During the recompletion and development of the well, the samples were collected for radiological and water quality analysis according to the FMP (DOE 2009a) and FI (DOE 2009c). Samples for tritium were collected and analyzed - and the results of sample analyses were documented-in accordance with the Radiological Control Manual. The following sections summarize the sampling activities.

\subsubsection{Radiological Sampling and Monitoring}

Samples were collected of the groundwater discharged during the reconstruction and development of well UC-1-P-1SRC. Samples were collected at various times during recompletion of the well, based on the activities being performed. Samples obtained during the development using an electric submersible pump were collected every 2 hours. All samples collected and analyzed during recompletion and development of the well indicated concentrations of tritium below background. Table D-3 in Appendix D provides the tritium results obtained during the recompletion and development of well UC-1-P-1SRC.

\subsubsection{Bromide and Water Quality Sampling}

Samples were collected of the groundwater discharged during the recompletion and development of well UC-1-P-1SRC. Samples were collected at various times during the recompletion, based on the activities being performed. Samples obtained during development using an electric pump were collected every 2 hours. Concentrations of bromide obtained from samples collected during 


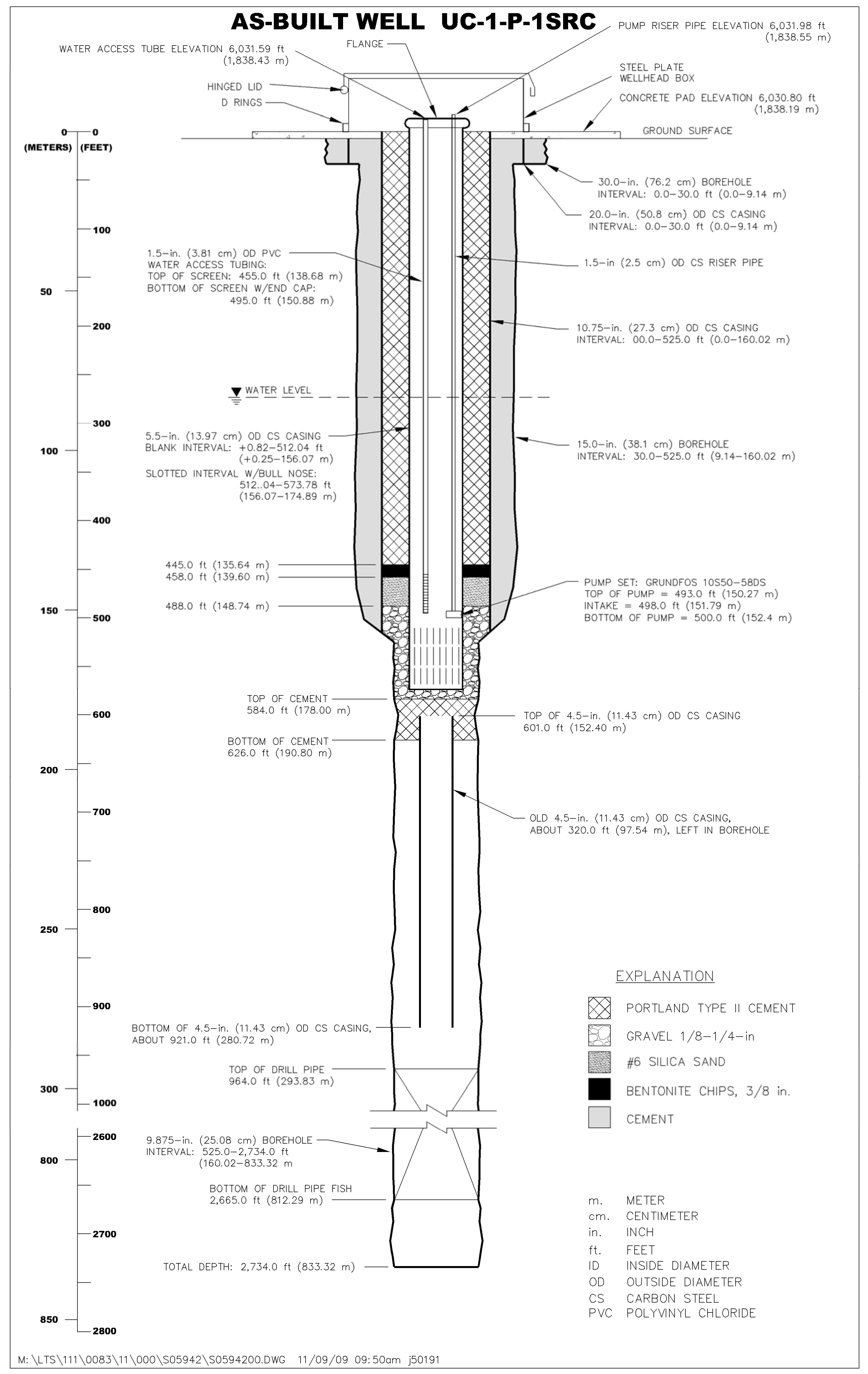

Figure 6-1. As-Built Well UC-1-P-1SRC 
This page intentionally left blank 
the recompletion ranged from 1.5 to $57 \mathrm{mg} / \mathrm{L}$. Results obtained from the final sample collected during the pump development indicated concentrations of bromide at $2.1 \mathrm{mg} / \mathrm{L}$ and turbidity of 5.75 NTU. Section 6.4 summarizes the well development activities. Table D-4 in Appendix D provides the groundwater quality parameter and bromide results obtained from well UC-1-P-1SRC.

\subsection{Pump Installation and Well Development}

Well UC-1-P-1SRC was completed with the 4-inch stainless-steel submersible Grundfos pump, model 10S50-58DS, with a 5-horsepower Grundfos motor that was removed from well MV-2. The dedicated, submersible electric pump was installed using the LX-29 pump rig, and the installation included setting the pump, riser pipe, and water-access tube. The installation of the pump was completed on June 6, 2009. The intake of the pump was set at approximately $498 \mathrm{ft}$ bgs. A new MS 4000 5-horsepower, 480-volt, three-phase Grundfos motor powers the pump because the original motor from well MV-2 failed. Power is supplied to the pump using No. 8 AWG 600-volt, heavy-duty, flat submersible cable that is banded and clamped to the 1.5-inch OD carbon-steel API pipe with EUE. The water-access tube is also banded and clamped to the 1.5-inch OD pump discharge pipe. The water-access tube is constructed with 1.5-inch-OD schedule-80 PVC pipe with flush joints. The water-access tube is completed with $40 \mathrm{ft}$ of 0.02-inch screen that is set just above the top of the pump. Refer to Table D-2 in Appendix D for the pump set specifications associated with well UC-1-P-1SRC.

The final development of well UC-1-P-1SRC was performed using the dedicated pump and began on June 9, 2009. Well development was performed during daytime operations and included approximately 6 hours of continuous pumping. Sample results obtained from the final sample during the development indicated bromide concentrations of $2.1 \mathrm{mg} / \mathrm{L}$, turbidity of 5.75 NTU, and tritium below background. Well development was completed on June 9, 2009. Fluid discharge rates averaged approximately 19 gpm, and approximately 7,000 gallons of fluid were removed during the development of well UC-1-P-1SRC. 
This page intentionally left blank 


\subsection{Summary of Well HTH-1RC Activities}

Well HTH-1 was the second of two existing wells to be recompleted during the drilling program at CNTA. This well was originally completed in September 1967 before the underground nuclear test and is approximately 2,900 ft south-southeast of SGZ (Figure 1-2). The well was constructed in a 12.25-inch borehole with a 9.625-inch-OD carbon-steel casing installed to a depth of 3,704 ft bgs. The well casing was cemented in place and perforated at various depth intervals from 150 to 3,665 ft bgs. At some time after the detonation, the well became obstructed at a depth of approximately $2,812 \mathrm{ft}$ bgs. The objective of the recompletion was to isolate perforations in the deep volcanic sediment above the obstruction and below the alluvium where groundwater is entering the well. The recompletion included the installation of two piezometers to isolate perforations in the alluvium, allowing head levels to be measured within three distinct hydrostratigraphic units (upper alluvium, lower alluvium, and volcanic sediment).

The recompletion of well HTH-1 began after the bladder pump was retrieved using the DH (LK-17) rig on May 26, 2009. The upper piezometer, lower piezometer, and well were completed on June 7, 2009, to depths of 1,038.60, 1,958.60, and 2,678.24 ft bgs, respectively. Airlift development of the well was conducted on June 7 and 8, 2009, and water-access tubing was installed on June 8, 2009. Upon recompleting well HTH-1, the location identification was changed to HTH-1RC. The following sections summarize the well construction, pump installation, and development activities. Refer to Table E-1 in Appendix E for a chronology of the recompletion activities at well HTH-1RC.

\subsection{Well Construction}

The recompleted well HTH-1RC was constructed within the existing 9.625-inch-OD carbonsteel casing with a 4.0-inch-OD carbon-steel casing. The well was screened from 2,357.75 to 2,658.05 ft bgs with manufactured 0.078-inch slotted casing. The well was completed to a total depth of 2,678.24 ft bgs, which included approximately $20 \mathrm{ft}$ of blank casing below the well screen for a sump. The lower and upper piezometers were constructed in the annular space between the 4.0-inch well casing and the existing 9.625-inch well casing. Both piezometers were constructed with 1.25-inch-OD carbon-steel flush joint casing with $60 \mathrm{ft}$ of manufactured 0.02-inch slotted casing. The lower and upper piezometers were completed to depths of 1,958.60 and 1,038.60 ft bgs, respectively. Refer to Figure 7-1 for a diagram showing the well construction details of HTH-1RC.

A graded filter pack was installed around the slotted intervals of the well and piezometers. Filter pack materials included $1 / 8$ - to $1 / 4$-inch clean gravel and No. 6 clean silica sand. A seal of $3 / 8$-inch bentonite chips was placed above each filter pack. The gravel filter pack was placed around the well and piezometer screen intervals, and the No. 6 silica sand was placed above the gravel. Gravel, sand, and bentonite chips were placed using a sand pump with a clean-water flush into the annulus between the two casings through a BQ tremie pipe. Portland Type II cement was used to seal the annulus above the well filter pack and bentonite seal to 1,980 ft bgs, approximately $20 \mathrm{ft}$ below the base of the lower piezometer. Similarly, cement filled the annulus from the top of the filter pack of the lower piezometer to 1,080 ft bgs, about $40 \mathrm{ft}$ below the base of the upper piezometer. Above the top of the upper piezometer filter pack, cement was used to seal the annulus to the surface. Cement was also pumped down the BQ tremie, followed by a clean-water rinse. The BQ tremie was raised in stages during placement of the stemming 
materials to help ensure proper placement without plugging or bridging. Table $\mathrm{E}-2$ in Appendix E lists well construction materials and volumes used to recomplete well HTH-1RC.

\subsection{Geophysical Well Logging}

The well and piezometer screen intervals for the recompleted well HTH-1RC were selected from geophysical logs obtained before the drilling program began at CNTA. Schlumberger collected the geophysical well logs on October 16, 2008. The objective of logging was to evaluate the integrity of the well casing and cement bond between the formation and casing for recompletion of the new well within the existing well. Results of the logging were used to design the new well that isolates perforations in the deep volcanic section from those in the overlying alluvium.

The existing well HTH-1 was logged using an assembled tool string approximately $60 \mathrm{ft}$ long. The bottom of the tool was lowered to the obstruction depth of 2,818 ft bgs. The water level was at a depth of $535 \mathrm{ft}$ bgs, and the bottom of the logged interval for the well was 2,772 $\mathrm{ft}$ bgs. A slim sonic logging tool and ultrasonic image tool were run in well HTH-1 to obtain a cement bond, variable density, casing corrosion, and gamma ray-collar logs. The cement bond log indicated a generally good bond between the casing and the formation down to about 2,360 ft bgs, with the exception of a short interval of poor bonding at approximately 1,320 ft bgs. Cement bond becomes increasingly poor below 2,470 ft bgs and is nearly nonexistent below 2,570 ft bgs. The gamma ray-collar log indicates casing thickness changes at approximately $950 \mathrm{ft}$ bgs, at approximately 1,150 ft bgs, and below 2,700 ft bgs. The casing thickness change below 2,700 ft might indicate a bent casing from the detonation. Refer to the end of Appendix E for a copy of the geophysical logs obtained from well HTH-1.

\subsection{Sampling}

Water samples were collected as part of the recompletion of well HTH-1RC. During the recompletion and development of the well, the samples were collected for radiological and water quality analysis according to the FMP (DOE 2009a) and FI (DOE 2009c). Samples for tritium were collected and analyzed — and the results of sample analyses were documented-in accordance with the Radiological Control Manual. The following sections summarize the sampling activities.

\subsubsection{Radiological Sampling and Monitoring}

Samples were collected of the groundwater discharged during development to monitor for tritium. Samples obtained during the development were collected from the discharge line approximately every hour. The samples analyzed during the development of well HTH-1RC indicated that concentrations of tritium were below background. Table E-3 in Appendix E provides the tritium results obtained during the development. 


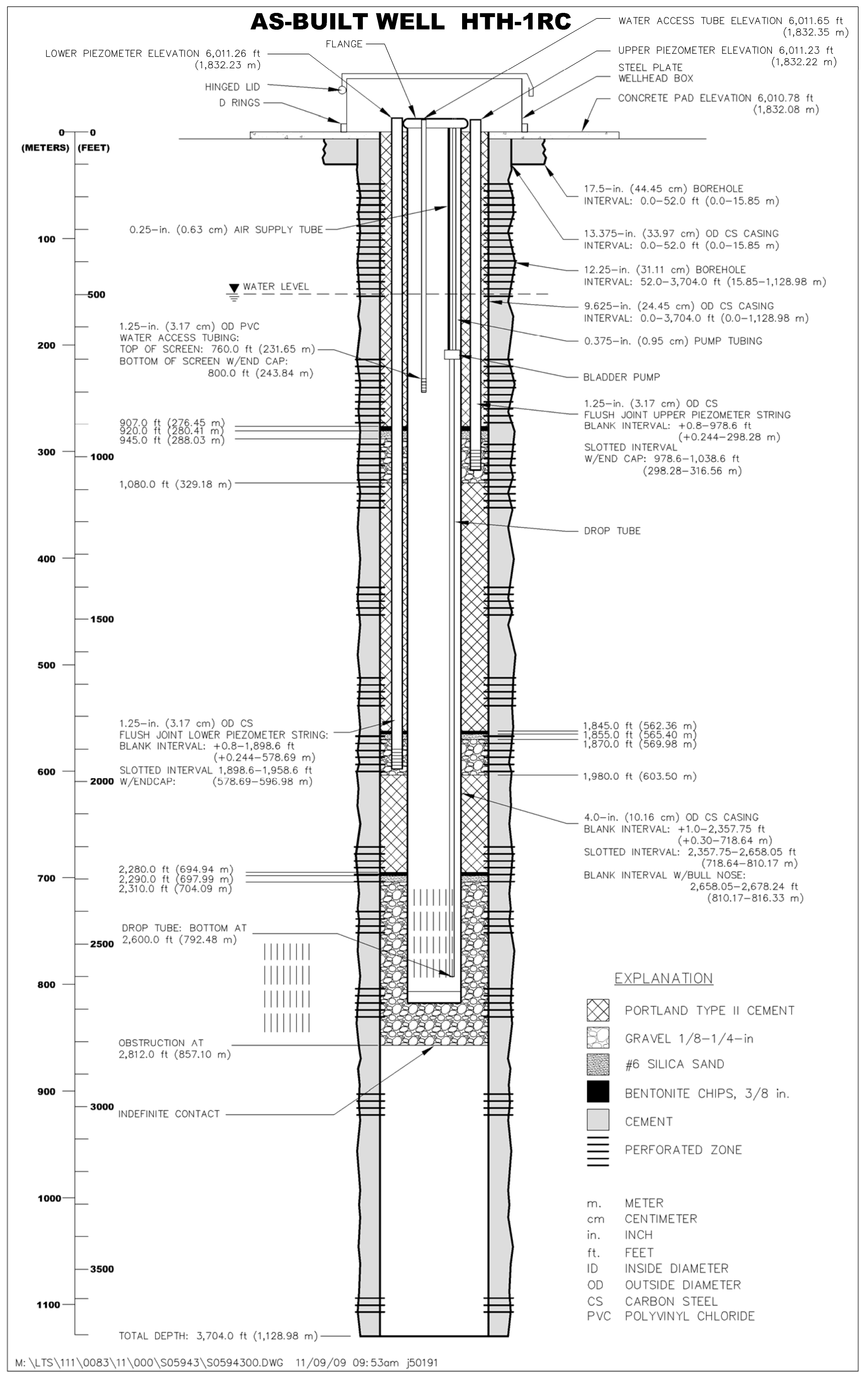

Figure 7-1. As-Built Well HTH-1RC 
This page intentionally left blank 


\subsubsection{Bromide and Water Quality Sampling}

Samples were collected of the groundwater discharged during development to monitor $\mathrm{pH}$, temperature, specific conductance, bromide, and turbidity. Samples obtained during the development were collected from the discharge line approximately every hour. Concentrations of bromide obtained from samples collected during the development ranged from 1.5 to $6.6 \mathrm{mg} / \mathrm{L}$. Results obtained from the final sample collected during development indicated bromide concentrations of $2.1 \mathrm{mg} / \mathrm{L}$ and turbidity of 50.5 NTU. Section 7.4 summarizes the well development activities. Table E-4 in Appendix E summarizes the water quality sample results.

\subsection{Development and Pump Installation}

The development of the recompleted well HTH-1RC began on June 7, 2009. The development consisted of airlifting and was performed with the DH (LK-17) drill rig using a 1,100 cfm air compressor plumbed to a BQ airline. The development included approximately 8 hours of airlifting and surging, and was completed on June 8, 2009. Fluid discharge rates averaged approximately 15 gpm, and approximately 7,000 gallons of fluid were removed during the development of well HTH-1RC. At the completion of development, a 1.25-inch-OD schedule-80 PVC water-access tube was installed to a depth of $800 \mathrm{ft}$ bgs. The water-access tube is completed with $40 \mathrm{ft}$ of 0.02 -inch screen. A low-flow bladder pump was then installed during a sampling event conducted the week of June 22, 2009. The bladder pump was set at $700 \mathrm{ft}$ bgs, and the drop tube/sample intake was set at approximately 2,600 ft bgs. Refer to Table E-2 in Appendix E for the pump set specifications associated with well HTH-1RC. 
This page intentionally left blank 


\subsection{Summary of Miscellaneous Well Site Activities}

The electric pumps in existing wells MV-1, MV-2, and MV-3 were removed, and the upper piezometers associated with wells MV-1 and MV-3 and the lower piezometer associated with well MV-2 were redeveloped as part of the drilling program at CNTA. Low-flow bladder pumps replaced the electric submersible pumps removed from wells MV-1, MV-2, and MV-3. The following sections summarize the pump removal and piezometer development activities.

\subsection{Removal of Electric Pumps and Installation of Bladder Pumps}

The submersible electric pumps in existing wells MV-1, MV-2, and MV-3 were removed as part of the drilling program at CNTA. Pump removal activities occurred during daytime hours and began at well MV-1 on May 18, 2009. The pump was removed from this well on May 19, 2009. It was determined that the motor associated with the pump had failed and needed to be replaced. A new MS 4000 5-horsepower, 480-volt, three-phase Grundfos motor was ordered and later reassembled with the pump. Pump removal activities were conducted at well MV-3 on May 19 through 21, 2009. The pump was removed from well MV-2 on May 22 and 23, 2009. It was determined that the motor associated with the MV-2 pump had also failed and needed to be replaced. A new MS 4000 5-horsepower, 480-volt, three-phase Grundfos motor was ordered and later reassembled with the pump.

The removed pump materials (riser pipe, PVC water-access tube, pump electric cable, pump motor, and pump) were evaluated, tested, replaced (if necessary), and installed in the new wells (MV-4 and MV-5) and the recompleted well (UC-1-P-1SRC). Low-flow bladder pumps were installed in wells MV-1, MV-2, and MV-3. The pumps were set in the existing wells MV-1, MV-2, and MV-3 at depths of 700, 500, and $900 \mathrm{ft}$, respectively. The drop tubes/sample intakes were set in wells MV-1, MV-2, and MV-3 at depths of 3,800, 3,100, and 4,100 ft, respectively.

\subsection{Redevelopment of Piezometers}

The upper piezometers associated with wells MV-1 and MV-3 and the lower piezometer associated with well MV-2 were redeveloped as part of the drilling program at CNTA. The redevelopment of the upper piezometers was conducted with a DH (LK-17) drill rig using a $1,100 \mathrm{cfm}$ air compressor plumbed to a 0.5 -inch airline. The development of the lower piezometer associated with well MV-2 was performed using a sand pump. The development was conducted to remove remnant drilling fluids and restore the natural hydraulic properties of the hydrostratigraphic unit.

Samples were collected during the redevelopment and analyzed on site for $\mathrm{pH}$, specific conductance, temperature, bromide, turbidity, and tritium. The results of the groundwater samples were used to determine the effectiveness of the development. Tables F-1 through F-3 in Appendix F provide the tritium results obtained during the redevelopment. Tables $\mathrm{F}-4$ through F-6 in Appendix F provide the water quality parameter results obtained during the redevelopment. 


\subsubsection{MV-1 Upper Piezometer}

The redevelopment of the upper piezometer associated with well MV-1 began on May 25, 2009. The redevelopment included approximately 13 hours of airlifting and surging. Results obtained from the final sample collected during the development indicated bromide concentrations of $1.2 \mathrm{mg} / \mathrm{L}$, turbidity of $39 \mathrm{NTU}$, and tritium below background. The redevelopment of the piezometer was completed on May 26, 2009. Fluid discharge rates averaged approximately 23 gpm, and approximately 11,000 gallons of fluid were removed from the MV-1 upper piezometer during the development.

\subsubsection{MV-3 Upper Piezometer}

The redevelopment of the upper piezometer associated with well MV-3 began on June 3, 2009. The redevelopment included approximately 19 hours of airlifting and surging. Results obtained from the final sample collected during the development indicated turbidity of $44.9 \mathrm{NTU}$ and tritium concentrations below background. The final samples were not analyzed for bromide, but samples at the beginning of the development were analyzed and indicated that concentrations of bromide were less than $1 \mathrm{mg} / \mathrm{L}$. The redevelopment of the piezometer was completed on June 4, 2009. Fluid discharge rates averaged approximately 20 gpm, and approximately 22,000 gallons of fluid were removed from the MV-1 upper piezometer during the development.

\subsubsection{MV-2 Lower Piezometer}

The redevelopment of the lower piezometer associated with well MV-2 began on May 26, 2009. During the redevelopment, the bailer associated with the sand pump got stuck in the lower piezometer at approximately 1,740 ft bgs. The bailer was removed on June 1, 2009. The redevelopment of the lower piezometer resumed on June 8, 2009; however, only a few gallons were removed because the cable had been damaged and was not long enough. The cable was replaced on June 12, 2009, and the redevelopment of the lower piezometer resumed. Approximately 15 gallons were removed, and redevelopment was completed on June 12, 2009. It was determined that not enough time was spent on the redevelopment of the lower piezometer; consequently Boart returned to the site to redevelop it on June 24, 2009. Approximately 45 gallons were removed from the lower piezometer, and redevelopment was completed on June 25, 2009. 


\subsection{Environmental Compliance and Waste Management}

The contractor was responsible for environmental compliance during the drilling program at CNTA. The environmental compliance elements of the drilling program included managing waste, tracking water use from well HTH-2 in accordance with waiver M/O-1515A, and managing fluids in accordance with the FMP. Copies of Material Safety Data Sheets for chemicals used during the drilling program were maintained on site. Spill response equipment was also maintained on site, and emergency contact information was made available to all employees at the site. The following sections summarize the environmental compliance and waste management activities.

\subsection{Waste Management}

Construction debris and nonhazardous waste were generated during the drilling program at CNTA. Construction debris and nonhazardous waste were contained in roll-off bins on site and disposed of by Boart. Incidental spills occurred during the drilling operations; however, no reportable spills (greater than 25 gallons) occurred during the drilling program. Secondary containment (e.g., plastic sheeting) was used under equipment to contain minor leaks that occur during operation. Fuel was stored in approved containers with appropriate labeling and secondary containment systems. Boart managed and disposed of hydrocarbon liquids and solids. No hazardous or radioactive waste was generated during the drilling program.

\subsection{Source Water Management}

The contractor monitored the use of water from well HTH-2 during the pad construction and drilling program in accordance with waiver M/O-1515A. A total of 148,200 gallons of water were removed from well HTH-2 during pad construction and 642,000 gallons of water were removed during the drilling program. The water removed from well HTH-2 during the pad construction and drilling program was temporarily stored in the lined sumps northwest of well HTH-2. A water truck was used to transport water used during the drilling program from the lined sumps to storage tanks on the drill pads. A flow meter was used to monitor the water use on the drill pads. It was determined that approximately 46,000 gallons of water were used during the drilling, construction, and development of well MV-4. The flow meter was not working during the drilling of well MV-5, but it is estimated from water hauling records that approximately 50,000 gallons of water were used during the drilling, construction, and development of well MV-5. Water was also used for dust suppression during the drilling program, and approximately 200,000 gallons remained in the lined sumps near well HTH-2 at the end of the project.

\subsection{Fluid Management}

Fluids generated during drilling, well construction, and development were managed in accordance with the FMP (DOE 2009a). The fluid management strategy was based on process knowledge, which was verified through field screening and on-site monitoring. Fluids produced during the drilling, well construction, and development were monitored on site for tritium. Tritium levels of discharged fluids remained within the background range during the drilling program. Infiltration basins were constructed near each well in accordance with the FMP (DOE 2009a). The infiltration basins contained fluids and cuttings from the drilling, 
construction, and development. The infiltration basins were surrounded by wattles and were not breached during the drilling program. 


\subsection{Site Health and Safety}

All work at CNTA was conducted in accordance with Title 10 Code of Federal Regulations Parts 835 and 851, the contractor's Integrated Safety Management System, and the FI (DOE 2009c). Additionally, all activities were conducted in compliance with DOE orders and Occupational Safety and Health Administration regulations. The health and safety training requirements, project information, site and material characteristics, hazard analysis, site controls, site operations, and emergency procedures were given to the subcontractor before the drilling project started and were outlined in Section 01020 (Construction Health and Safety), Attachment 1 of the CNTA drilling statement of work. Before arriving on site, all personnel that supported the CNTA project had appropriate and current health and safety training as specified in Section 01020, in the Job Safety Analyses (JSAs), or in both. Documentation of training was maintained on site during the project.

The JSAs developed for the project addressed the Integrated Safety Management System core functions - defining the scope of work and specific activities, analyzing the hazards associated with the activities, and developing and implementing the controls and protective equipment to mitigate those hazards. Two JSAs were prepared: one for monitor well installation and activities associated with the drilling, and one for the shuttle service. The JSAs were included as part of the required reading for the project, and all site personnel were required to sign them to indicate that they understood them. Contractor personnel conducted tailgate safety briefings and plan-ofthe-day discussions at the beginning of each work shift, through the duration of the project. All personnel who attended the briefings and discussions signed the necessary attendance sheets. Visitors and delivery personnel were given a tailgate safety briefing and were informed of the general hazards associated with the planned activities.

The success of the health and safety program at CNTA is directly attributable to the Integrated Safety Management System. The system was correctly implemented at the beginning of, and used throughout, the project. Adhering to the program caused work to be performed safely and demonstrated the system's effectiveness. 
This page intentionally left blank

Page 10-2 


\subsection{References}

10 CFR 835. U.S. Department of Energy, “Occupational Radiation Protection,” Code of Federal Regulations, January 1, 2009.

10 CFR 851. U.S. Department of Energy, “Worker Safety and Health Program,” Code of Federal Regulations, January 1, 2009.

Barnes, W. and Hoover, D.L., 1968. Preliminary lithologic log of drill hole UCE-20, Hot Creek Valley, Nye County, Nevada, U.S. Geological Survey Technical Letter, Central Nevada-15.

DOE (U.S. Department of Energy, Nevada Operations Office), 1999. Corrective Action Investigation Plan for the Central Nevada Test Area Subsurface Sites (Corrective Action Unit No. 443), Rev. 1, DOE/NV-483-Rev. 1, Las Vegas, Nevada, February.

DOE (U.S. Department of Energy), 2001. Closure Report for Corrective Action Unit 417:

Central Nevada Test Area Surface, Nevada, DOE/NV-743, Rev. 1, National Nuclear Security Administration Nevada Site Office, Las Vegas, Nevada, November.

DOE (U.S. Department of Energy), 2004. Corrective Action Decision Document/Corrective Action Plan for Corrective Action Unit 443: Central Nevada Test Area (CNTA)—Subsurface, Rev. 0, DOE/NV-977, National Nuclear Security Administration Nevada Site Office, Las Vegas, Nevada.

DOE (U.S. Department of Energy), 2006. Well Installation Report for Corrective Action Unit 443, Central Nevada Test Area, Nye County, Nevada, DOE/NV-1102, National Nuclear Security Administration, Environmental Restoration Division, Nevada Site Office, Las Vegas, Nevada, January.

DOE (U.S. Department of Energy), 2007. Corrective Action Plan Path Forward Proposal, Central Nevada Test Area, DOE-LM/1464-2007, prepared for the Office of Legacy Management, Grand Junction, Colorado.

DOE (U.S. Department of Energy), 2008a. Addendum to: Corrective Action Decision Document/Corrective Action Plan (CADD/CAP) for Corrective Action Unit (CAU) 443: Central Nevada Test Area (CNTA)—Subsurface, Central Nevada Test Area, Nevada, DOE/NV-977, Office of Legacy Management, Grand Junction, Colorado, January.

DOE (U.S. Department of Energy), 2008b. Responses to Comments on the Fluid Management Plan for Corrective Action Unit 443, CNTA, Subsurface Nevada Dated March 2008, Office of Legacy Management, Grand Junction, Colorado, August.

DOE (U.S. Department of Energy), 2009a. Fluid Management Plan, Central Nevada Test Area, Corrective Action Unit 443, LMS/CNT/S03736, Office of Legacy Management, Grand Junction, Colorado, January. 
DOE (U.S. Department of Energy), 2009b. Well-Site Fluid Management Strategy, Central Nevada Test Area, Corrective Action Unit 443, Document No. S05322, prepared for the U.S. Department of Energy Office of Legacy Management, Grand Junction, Colorado, April.

DOE (U.S. Department of Energy), 2009c. Field Instructions for Monitor Well Drilling and Completion Activities, Central Nevada Test Area, Corrective Action Unit 443, LMS/CNT/S04997-1.0, Office of Legacy Management, Grand Junction, Colorado.

DRI (Desert Research Institute), 1999. Evaluation of groundwater flow and transport at the Faultless underground nuclear test, Central Nevada Test Area, Publication 45165.

Ekren, E.B., E.N. Hinrichs, W.D. Quinliven, and D.L. Hoover, 1973. Geologic map of the Moores Station Quadrangle, Nye County, Nevada, U.S. Geological Survey Miscellaneous Investigations Series Map I-756, scale 1:48,000.

FFACO (Federal Facility Agreement and Consent Order), 1996 (as amended). Agreed to by the State of Nevada, the U.S. Department of Energy, and the U.S. Department of Defense.

Glasstone, S. and P.J. Dolan, 1977. The effects of nuclear weapons, 3rd edition, U.S. Department of Defense and U.S. Department of Energy.

Hoover, D.L., 1968a. Lithologic logs of drill holes in the Faultless area, Hot Creek Valley, Nevada, U.S. Geological Survey Technical Letter, Central Nevada-17.

McKeown, F.A., D.D. Dickey, and W.L. Ellis, 1968. Preliminary report on the geologic effects of the Faultless event, U.S. Geological Survey Report 474-65.

McKeown, F.A., and D.D. Dickey, 1969. "Fault displacements and motion related to nuclear explosions,” Bulletin of the Seismological Society of America, vol. 59, no. 6, p. 2253-2269.

NDEP (Nevada Division of Environmental Protection), 2008. Approval of Corrective Action Decision Document/Corrective Action Plan Addendum to Corrective Action Decision Document/Corrective Action Plan (CADD.CAP) for Corrective Action Unit (CAU) 443; Central Nevada Test Area (CNTA)—Subsurface Central Nevada Test Area, Nevada, DOE/NV-977, January 2008 Federal Facility Agreement and Consent Order, Letter, January 17.

Radiological Control Manual (LMS/POL/S04322), continually updated, prepared by S.M. Stoller Corporation for the U.S. Department of Energy Office of Legacy Management, Grand Junction, Colorado.

Snyder, R.P., 1967. Preliminary lithologic report on drill hole UCE-18, Hot Creek Valley, Nye County, Nevada, U.S. Geological Survey Technical Letter, Central Nevada-10. 